OPEN ACCESS

Edited by:

Alok Srivastava,

Christian Medical College,

India

Reviewed by:

Amir Ahmed Toor,

Virginia Commonwealth

University, USA

Guido Moll,

Charité University Hospital,

Germany

*Correspondence:

Marit Inngjerdingen

mariti@medisin.uio.no

Specialty section:

This article was submitted to Alloimmunity and Transplantation,

a section of the journal

Frontiers in Immunology

Received: 22 June 2016 Accepted: 18 August 2016 Published: 30 August 2016

Citation:

Boieri M, Shah P, Dressel $R$ and Inngjerdingen M (2016) The Role of Animal Models in the Study of

Hematopoietic Stem Cell

Transplantation and GvHD:

A Historical Overview.

Front. Immunol. 7:333.

doi: 10.3389/fimmu.2016.00333

\section{The Role of Animal Models in the Study of Hematopoietic Stem Cell Transplantation and GvHD: A Historical Overview}

\author{
Margherita Boieri, ${ }^{1,2}$, Pranali Shah ${ }^{3}$, Ralf Dresse ${ }^{3}$ and Marit Inngjerdingen ${ }^{1,2 *}$ \\ ${ }^{1}$ Department of Molecular Medicine, Institute of Basic Medical Sciences, University of Oslo, Oslo, Norway, ${ }^{2}$ Department of \\ Immunology, Oslo University Hospital, Oslo, Norway, ${ }^{3}$ Institute of Cellular and Molecular Immunology, University Medical \\ Center Göttingen, Göttingen, Germany
}

Bone marrow transplantation (BMT) is the only therapeutic option for many hematological malignancies, but its applicability is limited by life-threatening complications, such as graft-versus-host disease (GvHD). The last decades have seen great advances in the understanding of BMT and its related complications; in particular GvHD. Animal models are beneficial to study complex diseases, as they allow dissecting the contribution of single components in the development of the disease. Most of the current knowledge on the therapeutic mechanisms of BMT derives from studies in animal models. Parallel to BMT, the understanding of the pathophysiology of GvHD, as well as the development of new treatment regimens, has also been supported by studies in animal models. Pre-clinical experimentation is the basis for deep understanding and successful improvements of clinical applications. In this review, we retrace the history of BMT and GVHD by describing how the studies in animal models have paved the way to the many advances in the field. We also describe how animal models contributed to the understanding of GvHD pathophysiology and how they are fundamental for the discovery of new treatments.

Keywords: animal models, HSCT, aGvHD, cGvHD, pathophysiology

The use of animal models to study human diseases is considered essential for understanding underlying pathophysiological and molecular mechanisms (1). Here, we will review how animal models have contributed to understanding the complexity of hematopoietic stem cell transplantation (HSCT) and graft-versus-host disease (GvHD). HSCT is the treatment of choice to cure many types of malignant and non-malignant hematological diseases. Despite continuous improvements in the pre- and post-transplantation procedures, the survival rate of transplanted patients is still poor. Acute GvHD (aGvHD) or chronic GvHD (cGvHD) represents major complications after HSCT with high mortality rates, in addition to other complications, such as relapse of the malignancy, engraftment failure, or opportunistic infections. GvHD is evoked by immunocompetent cells present in the graft that recognize and attack host tissue in an immunosuppressed environment.

\section{THE HISTORY OF BONE MARROW TRANSPLANTATION}

The advent of the atomic age in the early 1950s led to a strong interest in developing means to protect or cure the potentially lethal effects of radiation. Exposure to high doses of radiation 
was recognized to have deleterious effects on hematopoiesis and immune cell functions. By using different animal models including mice, rats, and guinea pigs, researchers soon discovered that injection of bone marrow or fetal spleen cells into lethally irradiated animals could reconstitute the hematopoietic system (1-5).

At the time, it was not clear how reconstitution occurred. At first, all evidence suggested the presence of "humoral factors" that stimulated regeneration of the endogenous hematopoietic system (6), but several studies in the following years showed that the newly formed hematopoietic system was in fact originating from the donor. In one study, biochemical techniques were used to track rat bone marrow cells transplanted into lethally irradiated mice. The authors postulated that the intravenously injected cells were able to migrate to the bone marrow where they survived and maintained their ability to proliferate and form a new hematopoietic system (7). In another study, Ford and colleagues used chromosomal markers to track the donor cells in the recipient. Their experiments provided the final evidence that reconstitution was originating from donor-derived cells (8). The responsible cells in the graft were identified almost 10 years later when Till and McCulloch in 1963 described a single progenitor cell type in the bone marrow with the potential to expand clonally and to give rise to all lineages of hematopoietic cells. This represented the first characterization of the hematopoietic stem cell (9).

In 1956, Barnes and Loutit proposed that an irradiation-transplantation approach could be used to treat fatal hematopoietic malignancies, such as leukemia (10). They speculated that irradiation followed by injection of bone marrow could treat leukemia if leukemic cells were as sensitive to radiation as normal cells. They also hypothesized, in the same paper, that if the entire population of leukemic cells was not eliminated by radiation, a cure could perhaps be achieved with the injection of cells capable to induce an immune response toward the residual leukemic cells. With this central paper, they introduced the concepts of therapeutic bone marrow transplantation (BMT), graft versus leukemia (GvL), and cell therapy.

At that time, it was already well known that grafts between individuals of different genetic backgrounds were rejected, while transplantations between inbred animals or identical twins were successful. The first successful human BMT was performed in 1959 by Thomas and co-workers who treated two leukemic patients with irradiation followed by infusion of bone marrow from their homozygous twins ("autologous" transplantation) (11). Despite successful transplantation, both patients experienced relapse. Further animal experiments and human transplantations demonstrated that irradiation followed by autologous BMT was not enough to eradicate leukemia. As an alternative approach, transplantation of immune cells derived from an individual or animal with a different genetic background was proposed ("allogeneic," formerly termed "homologous"). This approach was experimentally tested in different mouse models $(10,12)$, resulting in successful eradication of the malignancies. Unfortunately, the mice died a few weeks later from what was then referred to as secondary or homologous disease. This disease was later defined as GvHD.

\section{GRAFT-VERSUS-HOST DISEASE}

The definition of GvHD is the result of a great number of accumulated observations since the 1940s. However, it was in particular the work of two independent researchers that elucidated the details of this phenomenon. Simonsen studied the acquisition of tolerance using chick embryos, and observed that injection of adult spleen or blood cells resulted in splenomegaly and severe hemolytic anemia in the recipient embryo. The rationale behind his experiments was that immunological competence is acquired after birth and, therefore, any immune effect in the adult to embryo transplantation setting is ascribable to the injected cells (13). During the same years, Billingham and Brent (14) performed similar studies in mice, describing splenomegaly, defects in growth, and early deaths when newborn mice were injected with allogeneic ("homologous") adult lymphoid tissues. The phenomenon was termed the "runt disease" due to the growth retardation of the mice. In 1959, the same authors concluded that runt disease resulted from a graft-versus-host reaction (GVHR). Their observations were similar to those of experimental BMT (15-18). In addition, several other research groups at the same time described a reaction of grafted immune cells against the host (19-22), and by the beginning of the 1960s the GVHR was an established caveat for successful BMTs.

The nature of the GvHD reaction was ascribed to immunocompetent cells present in the bone marrow graft. Initial the first experiments showed that different hematopoietic cell populations could be fractionated by centrifugation on discontinuous albumin gradients (23). Factions with low content of lymphocytes and high content of blasts were shown to induce less GvHD (24). The lymphocytes responsible for inducing GvHD was identified as T cells, demonstrated by depletion experiments, first with the use of anti-lymphocyte serum (ALS) $(25,26)$, and later confirmed by the use of various methods to specifically remove $\mathrm{T}$ cells from the graft (27-30). These findings represented an important step forward in improving the success of BMTs. The removal of T cells from the bone marrow graft was soon applied in the clinic, and the depletion methods were substantially improved. Unfortunately, while a reduction in GvHD was achieved, patient survival was not improved, since the absence of $\mathrm{T}$ cells led to increased relapse, higher risk of infections, and diminished engraftment. To overcome the detrimental effects related to $\mathrm{T}$ cell depletions and to boost the GvL effect, donor T cells was re-introduced after BM transplantation. The infusion was delayed to allow establishment of tolerance toward the host. Murine and canine models served well in testing the timing and protocols for $\mathrm{T}$ cell infusions, now termed donor lymphocyte infusion (DLI) (31-34).

The success of allogeneic transplantation depends on the degree of histocompatibility match between donor and recipient. Research on outbred canine models has been vital to study genes involved in histocompatibility, and the importance of 
tissue typing and donor selection. In intial experiments, antisera were produced by cross immunization of dog littermates. These antisera were used in cytotoxicity tests in order to establish matched donor/recipient pairs that proved to be effective in reducing, but not eliminating, GvHD occurrence. The number and nature of the allo-determinants were still unknown; however, it was already clear that histocompatibility antigens were allocated to different loci and that the potential presence of different alleles would make the selection of donor-recipient pairs difficult, especially in unrelated animals (35-37). In the following years, several studies, especially on canine models, were vital for understanding the mechanisms related to histocompatibility. Histocompatibility was shown to be linked to a particular genomic region called the major histocompatibility complex (MHC).

Differences in the genes of the $\mathrm{MHC}$ region between donor and recipient are the major cause of $\mathrm{T}$ cell allo-activation and GvHD induction, but there are also other genes involved. The first observations of allo-antigens encoded outside the MHC complex came from the above-mentioned studies on BMT in dogs. In some instances, dogs developed GvHD when transplanted with MHC-matched bone marrow (37). Subsequent studies in the mouse provided more evidence on the involvement of non-MHC antigens (38-40), called minor histocompatibility antigens (41). GvHD induced through mHA was also T-cell mediated as demonstrated by a series of T-cell depletion experiments $(42,43)$, but the manifestation of the disease was delayed compared to classical GvHD.

Graft-versus-host disease can develop in two different forms that differ in pathogenesis, symptoms, and organ involvement. aGvHD affects up to $50 \%$ of the patients and accounts for $15 \%$ of post-transplantation mortality (44). Classically, acute GvHD (aGvHD) develops during the first 100 days after transplantation, but late acute aGvHD has also been described. Typical target tissues for aGvHD are the gastrointestinal tract, skin, and liver, but other atypical tissues include kidneys (45), salivary glands (46), oral epithelium $(47,48)$, and thymus (49). cGvHD develops later, and it occurs in $\sim 50 \%$ of long-term survivors (50). Chronic GvHD (cGvHD) is associated with significant morbidity and mortality, and is still the leading cause of death in long-term survivors of HSCT (51). The organs involved are mainly skin, mouth, eye, and liver, and less frequently the gastrointestinal tract and lung. The pathogenesis of cGvHD is not clearly understood and the manifestations resemble more an autoimmune disease characterized by autoantibody production, chronic inflammation, and collagen deposition in target tissues.

\section{ACUTE GvHD}

\section{Pathophysiology of Acute GvHD}

Understanding the complexity of the process leading to aGvHD requires in-depth mechanistic studies to identify the involvement of the different components of the immune system. For this reason, a great deal of the knowledge on the pathophysiology of aGvHD is derived from animal models. In this section, we will review the seminal findings from animal models that have led to the current view of how aGvHD develops, which is acknowledged to progress through three phases: (i) activation

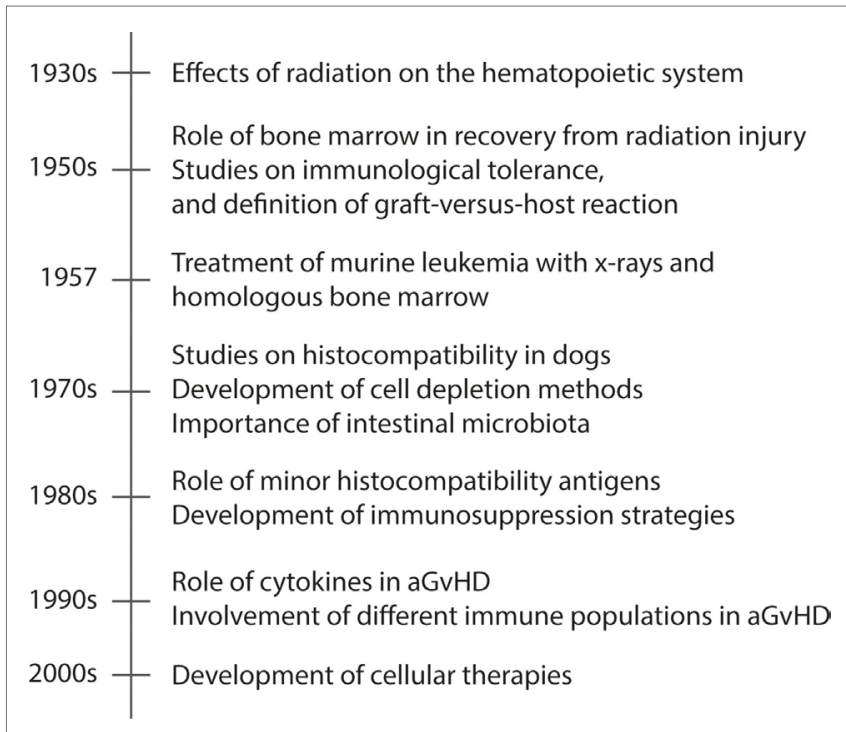

FIGURE 1 | A timeline presenting seminal events in animal models of aGvHD. Acute GvHD is caused by activated alloreactive donor T cells that directly cause tissue damage in target organs, such as skin and gut. The timeline shows the seminal findings in animal models that have led to the current understanding of aGvHD pathology.

of antigen-presenting cells (APCs), (ii) allo-activation of donor T cells, and (iii) tissue destruction by alloreactive T cells. A summary of these findings are found in Figure 1, while an overview of rodent aGvHD models is found in Table $\mathbf{1}$.

\section{The Conditioning Regimens Lead to Activation of APCs}

In the first phase, both the conditioning regimen and the underlying disease play central roles. Together, they create the tissue damage responsible for the production and the release of pro-inflammatory cytokines and chemokines that activate macrophages and APCs. Of particular importance is the damage to the intestinal epithelium caused by the conditioning regimens, and the subsequent release of microbial products, such as lipopolysaccharide (LPS) by the resident gut bacteria (82-84). After HSCT, we face the uncommon situation in which APCs from both host and donors are present. Using mouse recipients whose APCs were unable to cross-present class I restricted peptides, Shlomchik and colleagues demonstrated how host, rather than donor APC, are presenting allo-antigens to donor T cells (85). APCs are activated by many signals released during this early phase of inflammation, where cytokines, such as TNF- $\alpha$, IL-1, and IL-6, are central. These cytokines, apart from activating APCs, can also promote antigen presentation by nonprofessional APCs in the tissue and cause direct tissue inflammation that allows $\mathrm{T}$ cells to access their target tissues (86).

Total body irradiation (TBI) was the standard immunoablative procedure in the first years of BMT, and it is a widely used pre-conditioning method in animal models of HSCT. TBI is a very harsh procedure and causes significant damage to the fast-replicating tissues, such as skin and intestinal mucosa. Through research in murine and canine models, it was shown that the conditioning intensity and GvHD severity were directly 
TABLE 1 | Overview of rodent models for acute GvHD.

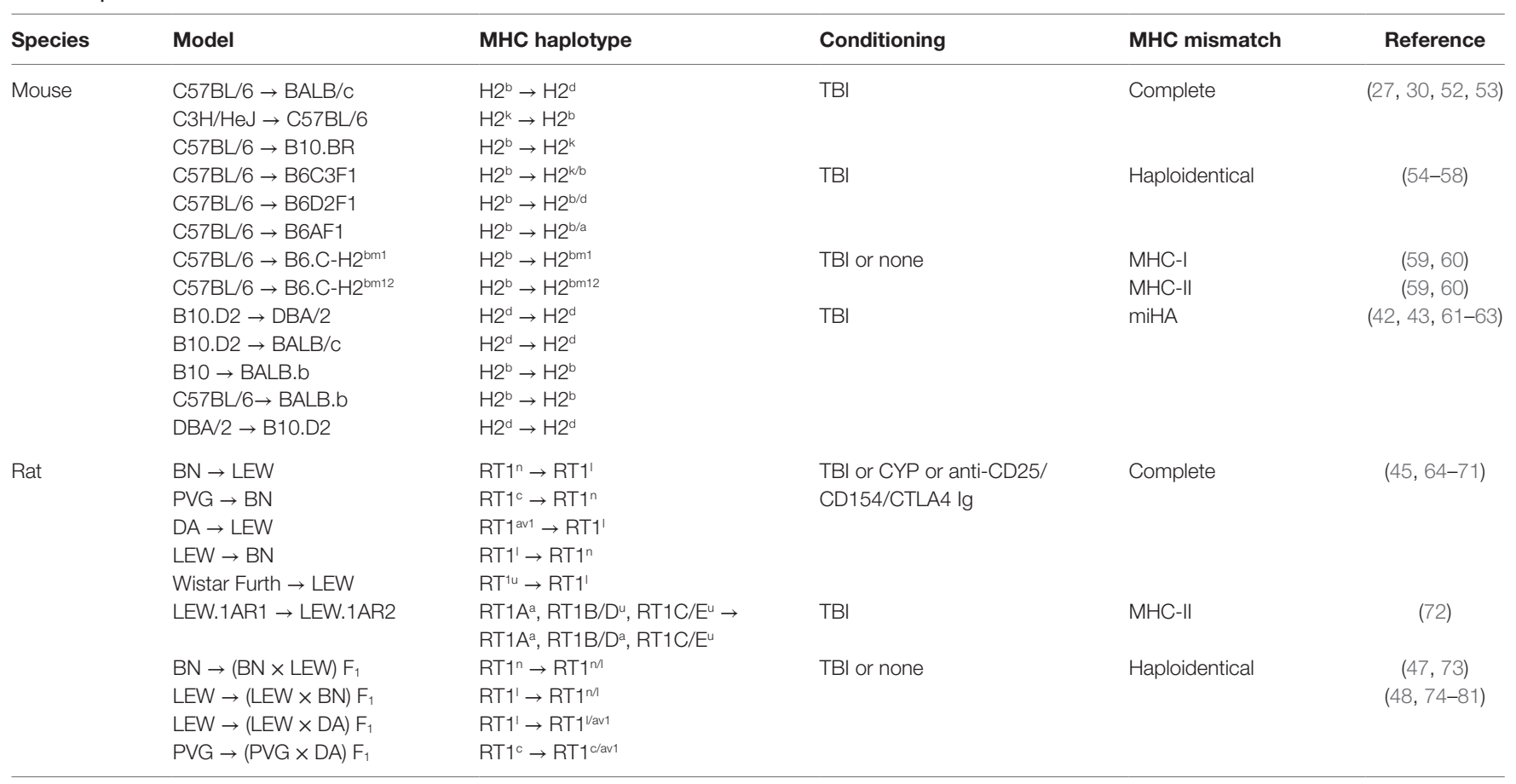

correlated $(83,87,88)$. Therefore, the development of milder conditioning regimens with less damage of the gut were rapidly developed in animal models and then brought to the clinic. At first, canine models showed that reduced intensity conditioning (RIC) led to graft rejection, but introduction of immunosuppression protocols post transplantation led to successful engraftment and reduced GvHD (87).

The role of the gut microbiota in the development of GvHD was first described in the early 1970s when experiments using germ-free mice showed that elimination of the gut microbiota reduced symptoms and mortality related to $\operatorname{aGvHD}(89,90)$. In the following years, gut decontamination using broadspectrum antibiotics was applied in clinical BMT. Results from clinical trials gave contrasting results and ultimately showed no increase in survival $(91,92)$. The reason is that the use of broad-spectrum antibiotics for gut decontamination does not take into consideration that the mutualistic relationship between patient and microbiota can be also protective in some instances. In more recent years, studies focusing on the composition of the microbiota have shown how the abundance of some bacterial species over others can protect or promote aGvHD. In particular, immunosuppressive treatments and aGvHD lead to loss in microbiota diversity, and the prevalence of members from the Enterobacteriales and Enterococcus order together with a loss in Clostridiales bacteria can promote aGvHD (93). The loss of Clostridiae species has important functional consequences since this population is thought to be an important promoter of regulatory $\mathrm{T}$ cell (Treg) proliferation and activity (94). The re-establishment of gut microbiota diversity through the introduction of probiotic therapy has been successful in reducing experimental aGvHD in mice (95).

\section{Alloreactive T Cells Are Activated in Secondary Lymphoid Tissues}

During the second phase, host APCs cross-present host autoantigens to donor $\mathrm{T}$ cells, which will be activated and start proliferating. The interaction between APCs and T cells is further enhanced by cytokines produced in the first phase (96). Furthermore, co-stimulatory molecules, including CD80 and CD86 expressed by APCs and CD28 expressed on T cells, give the classical second signal required for full $\mathrm{T}$ cell activation. Their expression is upregulated by the ongoing inflammation. The secondary lymphoid tissues of the gut are thought to be the primary site of $\mathrm{T}$ cell activation, as shown by experiments demonstrating failure to develop aGVHD in mice lacking Peyer's patches (PP) or where donor T cells lack the ability to migrate into PP (97).

The complex heterogeneity of $\mathrm{T}$ cell populations in humans makes it difficult to study the specific role of each subset, and how they may either promote or suppress aGvHD. Animal models are and have been essential for in-depth studies of the function of different $\mathrm{T}$ cell populations. For example, involvement of naïve rather than memory $\mathrm{T}$ cells in aGvHD has been investigated in mouse models. Several studies have shown how the transfer of purified effector memory CD44 ${ }^{+} \mathrm{CD} 62 \mathrm{~L}^{-} \mathrm{T}$ cells did not induce GvHD while retaining a GvL effect $(98,99)$.

$\mathrm{CD}^{+} \mathrm{T}$ helper $(\mathrm{Th})$ cells can differentiate into diverse subsets depending on the cytokines and microenvironment they are exposed to, and different Th subsets may be involved in aGvHD pathogenesis in distinct organs (100): Th1 cells, producing IFN- $\gamma$, IL-2, and TNF- $\alpha$, are mostly involved in the pathogenesis of gastrointestinal GvHD (101), while Th17 cells, producing IL-17A, IL-17F, IL-21, and IL-22, are thought to be the major pathogenic subset in skin GvHD (102). Only the simultaneous depletion of 
both these T helper populations is effective in controlling GvHD in mouse models (103).

The role of $\mathrm{B}$ cells in aGvHD is still controversial and under investigation. Host $\mathrm{B}$ cells have been shown, in mouse models, to be induced by TBI to produce IL-10 and contribute to reduce aGvHD occurrence (104). In previous studies in the rat, Renkonen and colleagues showed that, in lymphoid organs, there is increased $\mathrm{B}$ cell activation, proliferation, and antibody production early after BMT before the appearance of aGvHD symptoms. At later stages, the number of B cells decreased in the lymphoid compartment, but remained at high levels in the liver, suggesting a pathogenic role at least in this organ (105).

\section{Alloreactive T Cells Migrate to Target Organs and Mediate Tissue Destruction}

The third and last phase of aGvHD pathophysiology is the effector phase with migration of lymphocytes to their target tissues as one of the key steps. Chemokines and chemokine receptors specifically guide $\mathrm{T}$ cells in this process [reviewed in Ref. (106)]. CCR5 seems to have a broad effect as it has been described to mediate the recruitment of effector $\mathrm{T}$ cells, as well as Tregs, to many different target organs $(97,107,108)$. In gastrointestinal aGvHD CXCR3 (109), CX 3 CL1 (110), and CCR6 (111) has been shown to play additional important roles. Blocking the interaction between chemokine receptors and their ligands is one of the therapeutic strategies that are currently under investigation. Once $\mathrm{T}$ cells reach their target site, the tissue destruction occurs by direct induction of apoptosis mediated by TNF- $\alpha$ and IL-1 (112), and/or by killing mediated by cytotoxic CD8 ${ }^{+} \mathrm{T}$ cells through perforin/granzyme and Fas-FasL interactions. The suppression of $\mathrm{CD}^{+} \mathrm{T}$ cell function is crucial in the control of aGvHD (113).

The effector mechanisms in aGvHD have been studied in several mouse models. Donor spleen cells lacking both perforin and FasL failed at inducing aGvHD (114). Using different genetic combinations of donor and host mice, Graubert and colleagues showed that the perforin/granzyme pathway is mostly involved in MHC class I restricted aGvHD, while the Fas-FasL interaction is involved in MHC class II restricted aGvHD (115). A more recent study showed that $\mathrm{CD}^{+} \mathrm{T}$ cells deficient for both perforin and FasL can still induce aGvHD in a donor-recipient combination that differs at a single MHC class I antigen. In this model the serum levels of IFN- $\gamma$ and TNF- $\alpha$ were increased, and $\mathrm{CD}^{+} \mathrm{T}$ cells showed increased activation and proliferation. The authors concluded that both perforin and FasL are important during the contraction phase, and can contain the expansion of $\mathrm{CD}^{+} \mathrm{T}$ cells (116). T cell expressed TNF-related apoptosis-inducing ligand (TRAIL) induces proapoptotic signals upon binding to the TRAIL receptor on target cells, and is a commonly used killing pathway. Interestingly, this pathway has not been involved in tissue destruction in aGvHD, but it mediates anti-tumor responses. Murine T cells overexpressing TRAIL have been shown to suppress GvHD by inducing apoptosis of alloreactive $\mathrm{T}$ cells and mediating anti-lymphoma responses. The mechanism of action is thought to be through the interaction of the $\mathrm{TRAIL}^{+} \mathrm{T}$ cells with host
APCs bearing the TRAIL receptor DR5, but also fratricide of alloreactive T cells (117).

\section{Treatment of aGvHD}

The current standard treatment for aGvHD is the use of steroids in combination with calcineurin inhibitors. This treatment induces general immunosuppression, but has side effects. In addition, many patients with aGvHD are resistant to this treatment. There is, therefore, a need to improve treatments and to target specifically aGvHD, without affecting GvL. The complex pathogenic mechanisms described in the previous sections offers a variety of pathways as potential targets for new therapeutic protocols. Also in the development of treatments for aGvHD, animal models have been and will be extremely important, although the translation from the pre-clinical to clinical setting is not always straight forward as human pathology is more complex due to many varying environmental factors as we will discuss in more detail below. Nevertheless, the possibility of studying the mechanisms involved in the efficacy of different treatments in animal models is instrumental for designing safe and effective protocols in humans. We will review some treatment strategies, where the use of animal models has been essential.

\section{Immunosuppression}

Canine models have been essential for testing posttransplantation immunosuppressive therapies to ameliorate GvHD. Together with immunohistocompatibility matching and $\mathrm{T}$ cell depletion, the use of immunosuppressive drugs in the post-transplantation phase represents one of the major advances for GvHD-free BMT. This is especially the case for partial MHC-mismatched transplantation or for non-myeloablative RIC regimens prior to transplantation. Methotrexate (MTX) is an immunosuppressive drug that targets the production of folic acid, which is essential for the synthesis of nucleic acids and proteins. MTX was first tested in dogs and proved to be effective at reducing GvHD occurrence $(118,119)$. A few years later, the discovery of calcineurin inhibitors (e.g., cyclosporine A and tacrolimus) greatly improved the prophylaxis protocols. When used early after transplantation, these drugs, alone or in combination with MTX successfully reduced GvHD occurrence in animal models $(64,74,75,120-122)$, and were soon after introduced to the clinic, where the combined use of MTX and cyclosporine showed an advantage over cyclosporine alone $(123,124)$. Although protocols vary between clinical centers, a combination of calcineurin inhibitors, MTX, and antithymocyte globuline (125) is still the gold standard (126).

\section{Targeting of Cytokines}

TNF- $\alpha$ is one of the most important cytokines involved in the pathogenesis of aGvHD, implicated in many steps during the disease progression. The importance of this cytokine in aGvHD was first described in a mouse model (127). Since then several studies have shown how neutralization of TNF- $\alpha$ can lead to reduced symptoms of aGvHD, and different means to target TNF- $\alpha$ and its receptor interaction either post- (128) or pre-transplantation are currently being explored. 
IL-6 has a broad effect, activating many different immune cells. It has been associated with various inflammatory diseases, and has a predominant role in the early phases of aGvHD. Mouse studies have shown that IL-6 and its receptor (IL-6R) are upregulated during aGvHD (129), and that the addition of exogenous IL-6 can exacerbate the disease (130). Blockade of IL-6R were shown to reduce GvHD without affecting GvL (129, 131). Interestingly, mice treated with an anti-IL6R antibody also showed increased Treg reconstitution, which can effectively contribute to the reduction of aGvHD (131). A recently FDAapproved monoclonal anti-IL-6R antibody (Tocilizumab) has been shown to have beneficial effects in the treatment of steroidrefractory aGvHD (132).

The classical role attributed to IL-2 is to stimulate $\mathrm{T}$ cell proliferation. After many years of both experimental and clinical research, it is now clear that IL-2 has a more broad effect, including the maintenance of Treg homeostasis. Due to its effect on this regulatory population, IL-2 has been investigated as a therapeutic agent for treatment or prophylaxis of aGvHD. Administration of low doses of IL-2 alone has produced contrasting results in mouse models showing either beneficial (133) or no effects (134), but co-administration of rapamycin has been beneficial. Rapamycin targets conventional $\mathrm{T}$ cell signaling by blocking mTOR signaling. As Tregs use different signaling pathways, they are insensitive to rapamycin. In the presence of rapamycin, Treg do not compete with conventional T cells for IL-2 and this leads to their expansion (135).

The role of IL-18 and IL-22 in aGvHD pathogenesis is more controversial. ILC3 is a subset of innate lymphoid cells involved in maintaining gut homeostasis by producing IL-22, and is suggested to play a role in aGvHD pathogenesis. IL-22 is a cytokine with both protective and inflammatory functions, most likely depending on the microenvironment and the cell types involved (136). IL-22 produced by ILC3 targets epithelial cells, and regulates the production of anti-microbial factors, which are important in controlling the epithelial barrier function (137). In a mouse model, IL-22 depletion or deficiency in the host was shown to increase aGvHD severity, and ILC3 and IL-22 were suggested to protect the intestinal stem cell pool and epithelial barrier function during inflammation (138). Interestingly, in another mouse model, donor-derived IL-22 was shown to have the opposite effect and contribute to the severity of GvHD by promoting Th1 cell infiltration in presence of IFN- $\alpha$ (139).

\section{Targeting of Chemokines and Chemokine Receptors}

Blocking chemokine-chemokine receptor interaction is another logical therapeutic strategy that has been tested using animal models. Administration of anti-CXCR3 (140) or anti-CX ${ }_{3}$ CL1 (110) antibodies in mouse models of aGvHD were shown to reduce gastrointestinal aGvHD. CCR5 is involved in migration of lymphocytes to several target tissue of aGvHD, and for this reason, it appears as an interesting target molecule. However, targeting CCR5 has given contrasting results as this chemokine is thought to be involved also in Treg recruitment to peripheral tissues (141).

Another interesting approach to treat aGvHD has been to take advantage of the upregulation of CXCL10 (ligand for CXCR3) observed in target tissues during disease. By injecting
CXCR3-transfected Tregs, Hasegawa and colleagues showed specific migration of these cells to the target organs and subsequent reduction in aGvHD severity (142). Despite the encouraging results in animal models, it is important to keep in mind that the chemokine system is redundant, and blocking a single interaction does not always directly translate to a milder GvHD phenotype. For this reason, the use of agents with a broader effect that target more than one pathway has been tested. Among these, the broad-spectrum chemokine inhibitor NR58-3.14.3 has been successfully proved to reduce murine aGvHD especially in lung and liver (143).

\section{Targeting of Co-stimulatory Molecules}

Engagement of co-stimulatory molecules is necessary for full activation of T cells, and blocking these molecules has interesting potentials. Studies in animal models showed that anti-CD80 and anti-CD86 inhibited T cell expansion, and that mice treated with these antibodies experienced milder symptoms of aGvHD. Moreover, T cells isolated from CD28-deficient mice caused less severe GvHD $(144,145)$. Other studies have focused on targeting the CD40-CD40L pathway. Also in this case, the use of anti-CD40L antibodies reduced the severity of GvHD, which is thought to induce a selective depletion of activated $\mathrm{T}$ cells, and at the same time to induce Tregs (146-148). Along the same lines, the OX40-OX40L interactions are important in the pathogenesis of GvHD. T cells from rats with aGvHD upregulate OX40 (149), and administration of blocking antibodies against OX40L reduced aGvHD mortality in a mouse model (150). Other co-stimulatory pathways have been investigated in animals. Blockade of all of the following pathways have shown potential beneficial effects on aGvHD severity: 4-1BB/4-1BBL (151), ICOS/ICOS-L (152), LIGHT/HVEM (153), NKG2D-NKG2D-L (154), DNAM-1/DNAM-1-L (155), and the CD30/CD30L (156) pathways. However, co-stimulatory molecules are also important for the GvL effect, and blocking these molecules may severely compromise the GvL effect and, therefore, their clinical use may be limited. Nevertheless, experimental models suggest that not all molecules are equally involved in GvHD and GvL, and a better understanding of the importance of different co-stimulatory molecules for either GvHD or GvL may help identify new targets that can reduce GvHD while maintaining GvL.

\section{Cell Therapy}

Over the last 15 years, focus has been put on the use of cells with immunosuppressive functions to regulate $\mathrm{GGvHD}$, in particular mesenchymal stem cells (MSCs) and Tregs (157). MSCs are found at very low frequencies in the BM and other organs, such as adipose tissue, placenta, and amniotic fluid, and have the potential to differentiate into adipocytes, chondrocytes, myocytes, and osteoblasts. MSC support hematopoiesis in the BM (158), and contribute to embryo implantation by promoting trophoblast invasion in the placenta (159). MSC also have immunosuppressive functions which, together with the ease at expanding them ex vivo, have made them promising candidates for immunotherapy for aGvHD [reviewed in Ref. (160)]. Despite the initial success in the treatment of steroid-refractory aGvHD (157, 161), MSC therapy has failed to give consistent results 
and animal studies also show contrasting outcomes (65, 66, $76,162-167)$. Clinical trials testing the efficacy of MSC in the treatment of GvHD started before thorough investigation in preclinical models was completed (168). The precise mode of action of MSC on the immune system is not well understood, and these cells seem to acquire different functions according to the environment they are exposed to $(169,170)$. A better understanding of the biology of MSC, together with improved and standardized techniques for their isolation, characterization, and expansion may allow development of improved methods for their use in aGvHD prophylaxis or treatment. Tregs are a subset of $\mathrm{CD}^{+}$ $\mathrm{T}$ cells that represent $5-10 \%$ of the total $\mathrm{T}$ cell pool in human and rodents (171-173). Tregs express high levels of CD25 and the transcription factor FOXP3, which is necessary and sufficient for their immunosuppressive activity (174). The functional and phenotypical properties of Tregs are conserved in human and rodent species, making animal studies particularly relevant for applications in humans. Treg have immunosuppressive properties, and they are fundamental to induce and maintain peripheral self-tolerance, protecting from aberrant immune responses that can lead to excessive inflammation and autoimmunity. Earlier animal experiments showed that depletion of Treg from the BM graft resulted in severe aGvHD, with mice dying by day 21 after transplantation compared to day 41 in non-depleted transplantations (175). Moreover, addition of donor Treg to the graft at 1:1 ratio with conventional $\mathrm{T}$ cells was shown to delay or prevent aGvHD $(175,176)$. In order to exert their effects, Tregs must migrate to the secondary lymphoid tissues where alloreactive $\mathrm{T}$ cells are activated. For this reason, only the $\mathrm{CD} 62 \mathrm{~L}^{+}$and not the $\mathrm{CD}_{2} \mathrm{~L}^{-}$population of Tregs have been shown to protect from lethal aGvHD $(177,178)$.

Regulatory $\mathrm{T}$ cells are categorized into two groups, both important for controlling peripheral tolerance: naturally occurring Treg (nTreg) that develop in the thymus and induced Treg (iTreg) that differentiate from conventional $\mathrm{T}$ cells in response to TGF- $\beta$ and IL- 2 . The second group is therapeutically interesting because iTreg can be generated in vitro from conventional $\mathrm{T}$ cells (179), and they can be expanded to therapeutically sufficient amounts. Unfortunately, animal studies have shown that this approach does not lead to any protection from aGvHD. The main reason is that iTreg are unstable in vivo, and upon transfer they can lose the expression of FOXP3, together with their immunosuppressive activity $(180,181)$. One of the hypotheses to explain this instability is that the inflammatory environment of aGvHD can induce the conversion of iTreg back to conventional T cells. In favor of this hypothesis are studies showing how blocking inflammatory cytokines, in particular STAT3-dependent cytokines, can improve the iTreg stability $(182,183)$. The nTreg represent, therefore, a potentially more effective therapeutic tool, but their low frequency in the periphery requires optimization of ex vivo or in vivo expansion protocols.

Natural killer cells are another therapeutically interesting cell population in context of aGvHD and GvL. Earlier studies in rodent models demonstrated that NK cells are important for successful engraftment after BMT. NK cells are particularly radioresistant and can mediate rejection of allogeneic cells (184-186). The presence of residual NK cells after immune ablation can play a role in the acceptance or rejection of the allogenic graft. Studies in rats showed that differences in both the classical and non-classical MHC class I genes can contribute to NK-cell mediated rejection $(187,188)$. On the other hand, the infusion of alloreactive NK cells, together with a reduced TBI in a haploidentical transplantation mouse model, caused eradication of leukemia and depletion of the residual host hematopoietic system, thus facilitating the engraftment of donor BM cells. The additional NK-cell mediated killing of host APC prevents activation of alloreactive T cells and, therefore, no aGvHD (189). The use of NK cells to cause a GvL effect is restricted to those combinations of donor-recipient in which NK cell alloreactivity can be fully exploited (KIR-MHC mismatch). Moreover, not all types of tumor cells have the same sensitivity to NK cells due to variable expression of ligands for activating and inhibitory receptors. Additional stimulation of NK cells with cytokines might be required in order to accomplish an effective and long-lasting GvL effect for the NK-cell resistant tumors. A recent study demonstrated how NK cells pre-activated with a combination of IL-12, IL-15, and IL-18 reduced aGvHD while retaining the GvL effect in a fully mismatched BMT mouse model. Injected NK cells retained their activated phenotype and exerted their immunosuppressive activity by inhibiting alloreactive T cell proliferation (190).

\section{CHRONIC GvHD}

\section{Pathophysiology of Chronic GvHD}

Chronic GvHD in the clinic was initially defined as any symptoms of GvHD that occurred more than 100 days after transplantation, but it became increasingly clear that this definition was inadequate. Due to the heterogeneity of the clinical manifestations of cGvHD, cGvHD was only properly defined a decade ago with the NIH Consensus Project on cGvHD, and cGvHD is now classified as a disease distinct from aGvHD $(191,192)$. Both aGvHD and cGvHD arise as a complication of allo-HSCT transplantation, but with different pathology and underlying disease-driving mechanisms. Hallmarks of cGvHD in the clinical setting are systemic fibrosis, chronic inflammation, sclerodermatous manifestations, and autoantibody production. These features are similar to several autoimmune diseases; yet do not fully mimic any particular autoimmune disease, being an entity on its own. However, due to the pathological similarities between $\mathrm{cGvHD}$ and autoimmune diseases, there has been a close synergy between the two fields; the difference being that $\mathrm{cGvHD}$ is mediated by a foreign donor lymphoid graft.

Therapies directed at ameliorating cGvHD have improved little over the past decades. The reason is incomplete knowledge of the underlying mechanisms that drive the disease. This has been mainly due to lack of animal models that completely recapitulate the full clinical heterogeneity of cGvHD. For more than three decades after cGvHD was acknowledged in the clinic, the best described and most utilized animal models for $\mathrm{CGvHD}$ addressed only one or a few of the many clinical manifestations of cGvHD, principally autoantibody generation or sclerodermatous disease (193) (Table 2). The clinical relevance of these animal models was a concern, as they did not fully mimic the clinical setting in terms of composition of the donor graft, preparative regimens, 
TABLE 2 | Overview of rodent models for chronic GvHD.

\begin{tabular}{|c|c|c|c|c|}
\hline Species & Model & Conditioning & Manifestation & Reference \\
\hline \multirow[t]{10}{*}{ Mouse } & $\mathrm{C} 57 \mathrm{BL} / 6 \rightarrow \mathrm{B} 10 . \mathrm{BR}$ & Cy i.p./TBI & Bronchiolitis obliterans & (194) \\
\hline & $\mathrm{DBA} / 2 \rightarrow \mathrm{BALB} / \mathrm{c}$ & $\mathrm{TBI}$ & Scleroderm. & (195) \\
\hline & B10.D2 $\rightarrow$ DBA/2 × B10.D2 F1 & TBI & Scleroderm. & (186) \\
\hline & $\mathrm{B} 10 . \mathrm{D} 2 \rightarrow \mathrm{BALB} / \mathrm{c}$ & TBI & Scleroderm. & $(188,189)$ \\
\hline & $\mathrm{C} 57 \mathrm{BL} / 6 \rightarrow \mathrm{BALB} / \mathrm{c}^{\mathrm{a}}$ & $\mathrm{TBI}$ & Scleroderm. & $(190)$ \\
\hline & $\mathrm{BALB} / \mathrm{c} \rightarrow \mathrm{BALB} / \mathrm{c} \times \mathrm{A} / \mathrm{Jax} \mathrm{F} 1$ & None & SLE & $(185)$ \\
\hline & $\mathrm{DBA} / 2 \rightarrow \mathrm{DBA} / 2 \times \mathrm{C} 57 \mathrm{BL} / 6 \mathrm{~F} 1$ & None & SLE & (183) \\
\hline & $\mathrm{CBA} \rightarrow \mathrm{CBA} \times \mathrm{AF} 1$ & None & SLE & (193) \\
\hline & $\mathrm{C} 57 \mathrm{BL} / 6 \rightarrow \mathrm{C} 57 \mathrm{BL} / 6 \times \mathrm{BALB} / \mathrm{c}$ F1 & None & SLE & $(193,196)$ \\
\hline & $\mathrm{B} 6 \rightarrow \mathrm{B} 6 \times \mathrm{bm} 12 \mathrm{~F} 1 \mathrm{~F} 1$ & None & SLE & (197) \\
\hline Rat & $\mathrm{LEW} \rightarrow \mathrm{SD}$ & $\begin{array}{l}\text { SD neonates tolerized with LEW } \\
\text { lymphoid cells }\end{array}$ & Fibrosis & $(184)$ \\
\hline
\end{tabular}

a Low dose donor spleen cells prerequisite.

post-transplantation immune suppression, and the diverse human genetic background. Still, the animal models were instrumental for investigating subpopulations of donor and host leukocytes in the pathogenesis of cGVHD. In Figure 2, we have highlighted seminal findings from animal models. Moreover, during the last decade, improved models were developed that incorporate more of the features of clinical cGvHD, and these have led to further advances in our understanding of the underlying mechanism of cGvHD pathology.

\section{Lupus-Like and Scleroderma-Like Animal Models of cGvHD}

Chronic GvHD as a complication after allo-HSCT in the clinic was first acknowledged during the 1970s, with reports on autoimmune-like symptoms developing in patients several months after BMT. An autoimmune form of GvHD was described more than a decade earlier in experimental mouse and rat models. In 1961, Oliner, Schwartz, and Dameshek reported a form of GvHD ("runt disease") in a parent to F1 hybrid transplantation model with autoimmune characteristics similar to systemic lupus erythematosus (SLE) (197). Two years later, Stastny, Stembridge, and Ziff reported in the rat a chronic form of GvHD (termed "homologous disease") with features of sclerosing skin lesions similar to scleroderma (198). These works were followed by studies arguing that the "runting" syndrome of acute allogeneic disease must be separated from chronic allogeneic disease, the latter with symptoms manifesting at a later time point (199). It was suggested that, as for acute allogeneic disease, the chronic form was evoked by an immunological reaction of the donor against host antigens, although the exact mechanisms was not pinpointed at the time.

Throughout the 1970s and 1980s, the SLE-like and the scleroderma-like mouse models of cGvHD were the dominant animal models for $\mathrm{cGvHD}$. These models were also extensively used for studies of autoimmune diseases. The SLE-like models generally involved transfers of lymphoid cells from a parental strain into non-irradiated F1 hybrids [e.g., BALB/c to BALB/c $\times$ A/Jax F1 (199) or DBA/2 to C57BL/6 $\times \mathrm{DBA} / 2 \mathrm{~F} 1$ (197)], resulting in transient or mixed chimerism. The main manifestation in these models is generation of autoantibodies, while skin pathology is less common. The relevance of these models has been questioned, mainly due to absence of bone marrow derived stem cells in the

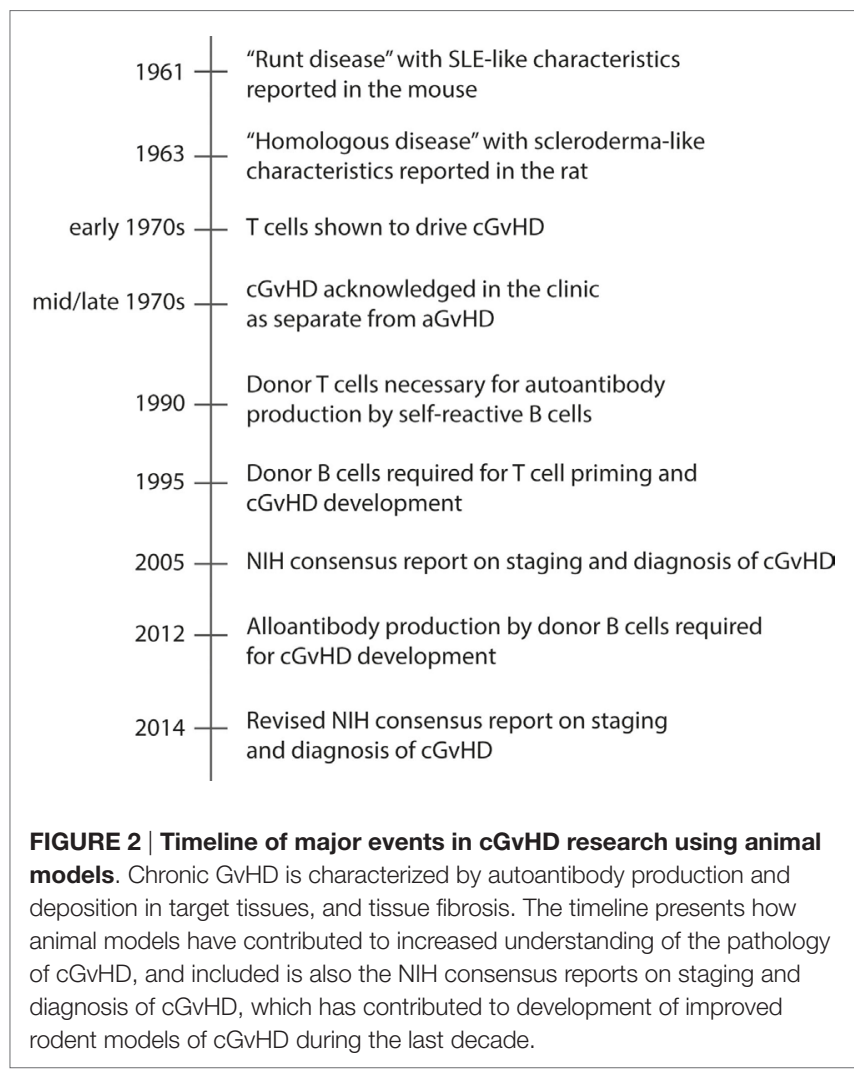

donor inoculum and absence of host immuno-depletion prior to transplantation.

Scleroderma-like mouse or rat models involves transplantation of major or minor MHC-matched or mismatched bone marrow into sub-lethally irradiated recipients, resulting in full donor chimerism (200-203). Here, the main manifestations are fibrotic changes in the skin, liver, lung, and salivary glands, while autoantibodies are less common. The scleroderma-like model for $\mathrm{cGvHD}$ shares many symptoms with sclerodermatous clinical cGvHD. The incidence of sclerodermatous $c \mathrm{GvHD}$ among long-term survivors of allo-HCST is around $3-10 \%$, but the incidence of sclerodermatous cGvHD in the clinic is expected to rise as increasing numbers of unrelated donor transplants are 
performed, as well as the increased use of mobilized peripheral blood as stem cell source.

More recently, developed mouse models have better recapitulated human cGvHD. In these models, transplantation of MHC-mismatched T cell-depleted bone marrow together with a low dose donor lymphocytes leads to cGvHD (196). Fibrosis of the skin, salivary gland damage, and serum autoantibodies are observed. Similarly, a mouse model developed in Blazar's laboratory with cyclophosphamide and lethal TBI pre-conditioning followed by allo-BM transplantation and low dose alloreactive $\mathrm{T}$ cell infusion, showed cGvHD manifestations in a wide range of cGvHD target organs (52). These models will likely significantly advance our understanding of the underlying immune reactions.

\section{Donor-Derived CD4 ${ }^{+} \mathrm{T}$ Cells as Initiators of cGvHD}

It was earlier shown that $\mathrm{T}$ cells play a central part for autoimmune development by collaborating with B cells for autoantibody generation (204). Fialkow and colleagues suggested that host $\mathrm{CD} 4^{+} \mathrm{T}$ cells were the drivers of autoantibody production, and that $\mathrm{cGvHD}$ was a purely host-derived, but graft-initiated, disease (205). However, it was soon clear that donor-derived $\mathrm{CD}^{+} \mathrm{T}$ cells were the real initiators of the disease, although the antigens recognized by the host-reactive donor $\mathrm{T}$ cells were not clear. Several pieces of evidence showed that naïve donor-derived $\mathrm{CD} 4^{+} \mathrm{T}$ cells were central for inducing cGvHD pathology, e.g., (i) when unfractionated lymph node cells or splenocytes were adoptively transferred into non-irradiated F1 hybrid hosts containing a mutated allele in MHC class I $(\mathrm{B} 6 \times \mathrm{bm} 1)$, a milder form of $\mathrm{cGvHD}$ was observed compared to transfer into F1 hybrid hosts with mutated MHC class II allele (B6 $\times$ bm12) (59), (ii) transfer of alloreactive donor CD4 ${ }^{+}$ $\mathrm{T}$ cells obtained from mice with aGvHD to lethally irradiated secondary hosts led to cGvHD (206), and (iii) mature donorderived $\mathrm{CD}^{+} \mathrm{T}$ cells were shown to cause both alloreactive and autoreactive responses using a DBA/2 to BALB/c cGVHD model (207). On the other hand, $\mathrm{CD}^{+} \mathrm{T}$ cells and the pool of $\mathrm{CD}^{+}$effector/memory T cells were found insufficient for inducing cGvHD $(98,208-211)$. Furthermore, depletion of CD8 ${ }^{+} \mathrm{T}$ cells from the graft, but not $\mathrm{CD} 4^{+} \mathrm{T}$ cells, led to autoantibody production. Later, a correlation was made between low $\mathrm{CD}^{+}$ $\mathrm{T}$ cell numbers with cGvHD severity in several parents into F1 hybrid models (212). Thus, there is a notion that the frequencies of donor alloreactive $\mathrm{CD} 8^{+} \mathrm{T}$ cells may determine whether aGvHD or cGvHD develops. For example, $\mathrm{CD}^{+} \mathrm{T}$ cell anergy can shift the responses from an aGvHD to an SLE-like cGvHD $(194,213)$. Although $\mathrm{CD}^{+} \mathrm{T}$ cells are not necessary to induce $\mathrm{cGvHD}$, they infiltrate skin and intestines where they contribute to the observed pathology (214).

\section{B Cells as Autoantibody Producers and APCs}

In contrast to aGvHD, B cells have a clear role in evoking cGvHD pathology. Although it was presumed that donor helper T cells were needed for production of autoantibodies by B cells, this was not directly shown until 1990, when Eisenberg's group utilizing a mouse model of SLE demonstrated that autoantibody production by self-reactive host B cells, and not donor-derived
B cells, was directly induced by donor-derived helper $\mathrm{T}$ cells $(195,215)$. The importance of B cells for inducing cGVHD pathology was subsequently shown by several investigators in SLE-like mouse models, by either blocking co-stimulatory molecules, such as CD40L and CTLA4, important for B-cell crosstalk $(146,216)$. Furthermore, B cell persistence, obtained by transferring perforin-deficient T cells from an aGvHD model (B6 into B6xDBA/2 F1 hybrids), resulted in a shift to cGVHD symptoms resembling SLE-like cGvHD (217). Later, in a mouse model of RIC, persistence of host B cells was associated with cGvHD lesions and autoantibodies of host origin (218). It was also shown that patients with extensive $\mathrm{cGvHD}$ had faster B cell recovery and detectable autoantibodies after allo-HSCT (219). Patients with severe cGvHD also have elevated levels of soluble B-cell activating factor (BAFF), which is evidence for activated B cells (220). Elevated BAFF serum levels were also associated with higher circulating levels of pre-germinal center (221) B cells and post-GC plasmablasts (222). Blockade of germinal centers with lymphotoxin-receptor Ig-fusion proteins was shown to suppress $\mathrm{cGvHD}$, further demonstrating the involvement of mature, activated B cells (223). Interestingly, transplantation of bone marrow incapable of secreting allo-antibodies resulted in less severe cGvHD, demonstrating a role for both auto- and allo-antibodies in cGvHD pathology (223).

In addition to their role as producers of autoantibodies, B cells are potent APCs that stimulate donor T cells to further propagate the cycle that leads to cGvHD. Priming of donor T cells to mHA and subsequent cGvHD development was shown to depend on B cells as APCs (224). Almost a decade later, it was shown for the first time in a clinical setting, that a coordinated $\mathrm{B}$ and $\mathrm{T}$ cell response to a $\mathrm{mHA}$, with donor $\mathrm{B}$ cells mediating the specificity, could be mounted in a setting of cGVHD (225). Further experiments in the mouse demonstrated that donor $\mathrm{B}$ cells promoted clonal expansion of autoreactive $\mathrm{CD} 4^{+} \mathrm{T}$ cells, their differentiation to the Th2 subset, and prolonged survival. In fact, these $\mathrm{T}$ cells mediate cGvHD when transferred into secondary recipients (226).

\section{Mouse Models Suggest That cGvHD Is a Th2-Driven Disease}

It has been debated whether cGvHD is primarily a Th1 or a Th2-driven disease. Most mouse models suggest that cGvHD is a Th2-driven disease. In the SLE-model, expansion of recipient $\mathrm{B}$ cells leading to lymphadenopathy, splenomegaly, and autoantibody production are observed. With this model, Th2 cytokines were shown to stimulate secretion of fibrosis-inducing cytokines (e.g., IL-13 and TGF- $\beta$ ) resulting in sclerodermatous disease $(208,209)$. When the cytokine balance was manipulated toward a Th1 type, a shift of symptoms to more aGvHD-like pathology was observed $(227,228)$. Furthermore, increased B cell activity was linked to increased levels of the Th2 cytokines IL-4 and IL-10, with concomitant suppression of IL- 2 and IFN- $\gamma$ by $\mathrm{T}$ cells isolated from animals with cGvHD (229). Confirming these observations, were clinical studies showing that a lack of Th1 responses led to early-onset cGvHD, and conversely, an early Th1 response with high IFN- $\gamma$ production was associated with less cGvHD (230). These observations were later confirmed in 
mouse models, demonstrating lower incidence of cGvHD in the presence of donor T cells producing high levels of IFN- $\gamma$ (221).

\section{Involvement of Thymic Dysfunction for cGvHD Development}

The thymus has a central role for both $\mathrm{T}$ cell development and for induction of $\mathrm{T}$ cell tolerance toward self antigens. Autoreactive $\mathrm{T}$ cells are negatively selected in this process. This is illustrated by studies of thymectomized neonatal mice that spontaneously develop multi-organ autoimmune disease $(231,232)$. Therefore, autoreactive $\mathrm{T}$ cells in context of cGvHD could result from defective tolerance induction due to thymic damage as a consequence of pre-conditioning or immune-mediated damage.

A mouse model of thymic dysfunction, where lethally irradiated hosts $(\mathrm{C} 3 \mathrm{H} / \mathrm{HeN})$ receive $\mathrm{T}$ cell-depleted bone marrow from MHC-mismatched, MHC class II deficient donors (C57BL/6) represent a model where impaired negative selection occurs as a consequence of lack of MHC class II expression by thymic dendritic cells. In this model, many features of clinical cGvHD are observed, including sclerodermatous skin disease, weight loss, fibrosis, inflammation, and immune cell infiltration of salivary glands, while autoantibody generation is not reported (233). A weakness of this model is the fact that host thymic medullary epithelium cells also mediate negative selection. In addition, in this model thymic function is constitutively impaired by lack of MHC class II molecules, and does not address whether there is a temporal window of thymic damage where impaired negative selection occurs. In another model, where sub-lethal irradiation of $\mathrm{BALB} / \mathrm{c}$ was performed prior to transfer of $\mathrm{MHC}$-matched, mHA-mismatched DBA/2 bone marrow, donor T cells caused lesions characteristic of $\mathrm{cGvHD}$ when transferred to secondary allogeneic recipients. These cells were shown to be thymopoiesis dependent, and the authors, thus, concluded that T cells generated in the thymus were responsible for cGvHD development (206). Of note, a previous study using the same animal model could not demonstrate thymic dependence for cGvHD development (234).

A number of other mouse models points against a role for the thymus in the induction of $\mathrm{cGvHD}$, as none of the murine models involving genetically unmodified mice has provided any evidence of impaired negative selection. In particular, no adversities of the thymic architecture or $\mathrm{T}$ cell development has been observed in the well-described SLE or Sclerodermamodels described in the previous sections. Moreover, transfer of DBA/2 splenocytes and bone marrow to thymectomized $\mathrm{BALB} / \mathrm{c}$ hosts did not change the incidence or the severity of cGvHD compared to mice with intact thymus (235). However, recent years' research has indicated that alloreactive donor $\mathrm{CD}^{+} \mathrm{T}$ cells may damage thymic epithelial cells, leading to generation of autoreactive T cells $(196,236)$. The resulting autoreactive $\mathrm{T}$ cells were demonstrated to interact with donor $\mathrm{B}$ cells resulting in autoantibody production (196). Although recently developed mouse models strongly suggest that dysfunctional thymic negative selection is important for CGvHD pathogenesis, a role for the thymus in human cGvHD pathology is not clear. In addition, one must bear in mind that the thymus involutes by age, and older patients are not likely to have abundant functional thymic tissue.

\section{Treatment of cGvHD}

Current treatment of cGVHD is largely based on immunosuppressive steroids, but development of more targeted therapies to replace or to treat steroid-refractory $\mathrm{cGvHD}$ are currently tested in pre-clinical animal models and several have now entered clinical trials.

\section{Inhibition of Fibrosis}

Platelet-derived growth factor (PDGF) and TGF- $\beta$ are both pro-fibrotic cytokines inducing fibroblast activation. cGvHD patients are shown to have elevated levels of circulating, stimulating autoantibodies toward PDGFR $\alpha$. PDGFR signaling leads to enhanced reactive oxygen species generation and subsequent collagen synthesis and deposition. Mouse cGvHD models were instrumental for developing Imatinib, a tyrosine kinase inhibitor that targets PDGFR $\alpha$ (41), and also anti-TGF- $\beta$ treatment was shown to prevent skin and lung fibrosis (237). Imatinib has shown promising results in clinical trials of steroid-refractory cGvHD patients $(238,239)$. An enhanced effect was observed by simultaneous targeting of both PDGFR $\alpha$ - and TGF- $\beta$ signaling pathways using Imatinib and Nilotinib, the latter targeting $c-A b l$ in the intracellular pathway induced by TGF- $\beta$ (240).

\section{Targeting of B Cells}

As donor-derived B cells are central auto- and allo-antibody producers, and significantly contribute to clonal expansion of donorderived $\mathrm{CD} 4^{+} \mathrm{T}$ cells, therapies have been directed at depleting $\mathrm{B}$ cells from the patients. The well-known B cell-depleting antibody Rituximab (anti-CD20) specifically targets B cells and has been used in the treatment of patients with refractory $c \mathrm{GvHD}$, resulting in objective improvements of symptoms (241-243). However, the antibody rarely results in complete remission of cGvHD. It is also a concern that anti-CD20 antibodies poorly target germinal centers in lymph nodes, in contrast to efficient removal of B cells from peripheral blood (244).

\section{Infusion or Induction of Tregs}

As for aGvHD, the use of Tregs in therapy of cGvHD is being exploited in clinical trials, as cGvHD patients have reduced frequencies of Tregs similar to aGvHD patients $(245,246)$. In mouse models, it was shown that transfer of ex vivo expanded Tregs resulted in suppression of cGvHD (247), suggesting that they may be utilized to treat $\mathrm{cGvHD}$. However, the required ex vivo expansion of Tregs to obtain sufficient numbers for transfer into patients is technically challenging, and may also be associated with changes in their functionalities as discussed above. Another strategy is the expansion of Treg in vivo by injecting low-dose subcutaneous IL-2 leading to increased Treg accumulation that has demonstrated reduced severity of cGvHD (248).

\section{ADVANTAGES AND LIMITATIONS OF ANIMAL MODELS FOR GVHD}

As outlined above, animal models have largely contributed to current GvHD prophylaxis and treatment protocols (249). 
An overview of the most common animal models are found in Tables 1 and 2. Each model has advantages but also their limitations.

In the early days of GvHD research, canine models were important for studying the role of MHC disparities in GvHD (250), and the canine models substantially contributed to advance our understanding of the biological mechanisms at play in HSCT and GvHD. Among the many researchers in this field, Edward Donnal Thomas is often recognized as the father of clinical BMT, for which he earned the Nobel Prize of Medicine in 1990. In addition to his clinical work, he carried out intensive research in canine models of BMT and GvHD. Canine models are still used in studies pertaining to the effectiveness of cellular immunotherapy, such as the utility of an anti-CD28 antibody as therapy to prevent GvHD during allo-HSCT (251).

Although outbred animal models are sometimes required to better mimic several aspects of human HSCT and GvHD, the most preferred animal model in context of GvHD is currently the mouse (252). The advantages of mouse models are the (i) broad availability of transgenic and gene-deficient strains that provide mechanistic insights into the role of individual genes for GvHD (253), (ii) the presence of inbred strains that are well characterized for studying GvHD and GvL, (iii) the availability of many well-characterized reagents, and (iv) the relative low costs of breeding mice $(254,255)$.

Several well-characterized mouse models of both acute and cGvHD have been established, such as the full MHC class I mismatch $\mathrm{C} 57 \mathrm{BL} / 6$ to $\mathrm{BALB} / \mathrm{c}(256)$ or $\mathrm{C} 3 \mathrm{H} / \mathrm{HeJ}$ to $\mathrm{C} 57 \mathrm{BL} / 6$ (30) for aGvHD, and B10.D2 to BALB/c for cGvHD. The mouse is a particular valuable model to determine the role of individual cell types, genes and factors that affect GvHD. Examples are transgenic mice that have a mutant MHC class I, e.g., B6.C-H2 ${ }^{\mathrm{bm} 1}$ (bm1), or mutant MHC class II, e.g., B6.C$\mathrm{H} 2^{\mathrm{bm} 12}$ (bm12). Both the $\mathrm{H} 2^{\mathrm{bm} 1}$ and $\mathrm{H} 2^{\mathrm{bm} 12}$ models have been important in understanding the interaction of $\mathrm{T}$ cells with recipient and donor APCs (257). Humanized murine models are also interesting models for GvHD and GvL research (258). An example is the Hu-PBL-SCID model, which is based on the NOD-scid mice. In this model, HIV-1 envelope protein gp120 delayed GvHD development by activation of human Tregs (259). Similarly, GvHD development was delayed in the $\mathrm{Hu}-\mathrm{PBL}-\mathrm{SCID}$ model based on NOD-scid IL $2^{\text {null }}$ mice following treatment with a soluble Fas ligand (260). On examination of the kinetics of engraftment and development of GvHD in the latter model, it was observed that mice deficient in MHC class I exhibited a delay in GvHD (261). However, it is difficult to select an appropriate model, as engraftment or the strength GvHD symptoms does not necessarily correlate with the pathophysiology of GvHD in humans (262).

Rats are also used for GvHD studies. Rats are genetically similar to mice, but they are larger in size, have a longer life span, and have more biomaterial that can be used for experiments (263). GvHD models in rats include MHC-mismatched strains between LEW and BN $(264,265)$, or between PVG and BN $(67,68)$. Rat models have been used to test immunomodulatory drugs such as Thalidomide (266) and MC1288, an analog for vitamin D (267) as therapeutic strategies for GvHD.
Conditioning prior to transplantation causes tissue damage and pro-inflammatory responses that affect the GvHD outcome $(268,269)$. Therefore, the timing of transplantation and conditioning regimens will significantly affect the experimental outcome (270). Conditioning regimens in murine models frequently involves TBI, in contrast to the clinical settings where patients are usually given chemotherapy, and where only a few patients are subjected to TBI (271). Sadeghi and colleagues developed a chemotherapy-based GvHD mouse model with busulfan and cyclophosphamide as the conditioning regimen. The mouse model was mismatched for both MHC and mHA [C57BL/6 $\left(\mathrm{H} 2^{\mathrm{b}}\right)$ to $\left.\mathrm{BALB} / \mathrm{c}\left(\mathrm{H}_{2} \mathrm{~d}\right)\right]$, and the allogeneic transplanted mice developed clinical and histological symptoms associated with GvHD, such as apoptosis and $\mathrm{T}$ cell infiltration into the target organs (272). This model represents a myeloablative-conditioning regimen, which is most commonly used in the clinic. Another mouse model involving the same chemotherapy as conditioning was described using MHC-matched, mHA-mismatched mice $\left[\mathrm{LP} / \mathrm{J}\left(\mathrm{H} 2^{\mathrm{b}}\right)-\mathrm{C} 57 \mathrm{BL} / 6\left(\mathrm{H} 2^{\mathrm{b}}\right)\right]$. This model was developed to more closely mimic the clinical situation, where patients usually are MHC matched. With this model, similar $\mathrm{T}$ cell infiltration, GvHD-specific damage, and systemic inflammation were observed in the mice as reported in humans (273). Thus, animal models of selective mHA mismatch may represent human HSCT more closely than MHC-mismatched models (193).

Another important consideration is the fact that the immune cell compositions vary between species. In murine models, mice receive bone marrow and $\mathrm{T}$ cells from an allogeneic counterpart to induce severe aGvHD. The T cell expansion is mainly homogeneous in the inbred recipients, in contrast to the heterogeneous $\mathrm{T}$ cell response in humans (274). Furthermore, differences in the proportion of lymphocyte subsets (such as $\mathrm{CD} 4^{+}, \mathrm{CD} 8^{+}$, and Tregs) between species can influence pathophysiology of GvHD (193). In addition, the metabolism and pharmacology of animal models can be different and these differences between animal models and humans could explain why some of the findings in mice models have not been successfully translated into clinical trials. For example, IL-11 reduced transplant related mortality (TRM) and prevented GvHD while maintaining GvL effects in mice (275). By contrast, IL-11 included as GvHD prophylaxis caused multi-organ failure in a phase I/II double blinded, placebo-controlled trial for allo-HSCT (276). In another example, experiments in mice showed that GvHD was effectively prevented in animals by therapy with a monoclonal antibody against the IL-2 receptor (IL-2R) (277). However, the use of IL-2R antibodies in two separate clinical trials was only moderately successful in reducing the incidence of severe $\operatorname{GvHD}(278,279)$.

An important difference between mouse and rat animal models and humans is the homogenous genetic composition of inbred rodents, in contrast to the heterogeneous humans (193). Furthermore, the genetic drift that occurs in inbred strains from a particular colony might affect the ability to reproduce data consistently between labs (280). Given that inbred strains are an artificial model, several different inbred strains and/or outbred animals should be used to better represent the genetic complexity in the human population. For this reason, canines are sometimes 
preferred to study new regimens in prophylaxis and treatment of GvHD (281).

Moreover, there are important species differences that need to be taken into consideration when extrapolating results found in animal models to humans (282). Differences in the anatomy, physiology, microbiota, play an important role in GvHD pathology (193). In addition, age plays an important role in influencing the efficacy of immune reconstitution post-transplant, as well as susceptibility to GvHD (283). Non-human primates or canine models are better fit for long-term therapies, given their longer life span than rodents. Moreover, the effects of opportunistic infections that affect HSCT outcome that can be observed in humans are not modeled in rodents kept in SPF conditions.

An alternative to study GVHR is the use of the skin explant model. The skin explant model can closely mimic the in vivo mechanisms and pathology of human $\operatorname{GvHD}(284,285)$. The skin explant assay for GvHD was initially tested as a method to predict incidence and severity of GvHD in humans (286), and we have previously shown that a rat skin explant assay for GvHD is useful to determine the severity of GvHD between different rat strains (287). Although in vitro studies can provide hypotheses and models for research, there is a strong need for testing and validation in an in vivo animal model. The important pathophysiological conditions and symptoms of GvHD have been successfully reproduced in a number of animal models (288), and animal models have been very useful in understanding various key mechanisms of GvHD and GvL. However, they still fail to fully compensate for the variable time of onset of the disease, the rate of progression, relapse of primary disease, and other important clinical variables attributed to GvHD pathology and HSC outcome (288). Till date, researchers have failed to create accurately an animal model encompassing all human parameters (289). Identifying suitable models for specific fields would be beneficial.

\section{REFERENCES}

1. Jacobson LO, Simmons EL, Marks EK, Eldredge JH. Recovery from radiation injury. Science (1951) 113:510-1. doi:10.1126/science.113.2940.510

2. Jacobson LO, Simmons EL, Marks EK, Robson MJ, Bethard WF, Gaston EO. The role of the spleen in radiation injury and recovery. J Lab Clin Med (1950) 35:746-70.

3. Patt HM, Tyree EB, Straube RL, Smith DE. Cysteine protection against X irradiation. Science (1949) 110:213-4. doi:10.1126/science.110.2852.213

4. Congdon CC, Uphoff D, Lorenz E. Modification of acute irradiation injury in mice and guinea pigs by injection of bone marrow; a histopathologic study. J Natl Cancer Inst (1952) 13:73-107.

5. Lorenz E, Uphoff D, Reid TR, Shelton E. Modification of irradiation injury in mice and guinea pigs by bone marrow injections. J Natl Cancer Inst (1951) 12:197-201.

6. Jacobson LO. Evidence for a humoral factor (or factors) concerned in recovery from radiation injury: a review. Cancer Res (1952) 12:315-25.

7. Nowell PC, Cole LJ, Habermeyer JG, Roan PL. Growth and continued function of rat marrow cells in x-radiated mice. Cancer Res (1956) 16:258-61.

8. Ford CE, Hamerton JL, Barnes DW, Loutit JF. Cytological identification of radiation-chimaeras. Nature (1956) 177:452-4. doi:10.1038/177452a0

9. Becker AJ, Mc CE, Till JE. Cytological demonstration of the clonal nature of spleen colonies derived from transplanted mouse marrow cells. Nature (1963) 197:452-4. doi:10.1038/197452a0

\section{FUTURE PERSPECTIVES}

Overall, substantial progress has been made using animal models to understand GvHD. However, major clinically relevant questions still remain unanswered. It is important to understand the mechanisms involved in the effect of RIC on late-onset aGvHD, for instance, or the mechanisms involved in steroid-resistant disease (290). In spite of distinctive similarities of GvHD pathology between different animal models and humans, the corollary question remains: Do animal models, in absence of immunosuppressive medications post transplantation, adequately simulate GvHD that occurs in humans (291). Designing interventions using animal models involving mimicry of the experience of the patient during their treatment in the clinic could be important. Larger animal models or non-primate humans could be used to investigate steroid resistance, secondary treatments, and also monitor these effects long term.

\section{AUTHOR CONTRIBUTIONS}

$\mathrm{MB}, \mathrm{PS}$, and $\mathrm{MI}$ wrote the manuscript; $\mathrm{MB}, \mathrm{PS}, \mathrm{RD}$, and $\mathrm{MI}$ planned the contents; RD and MI reviewed the contents.

\section{ACKNOWLEDGMENTS}

The authors would like to thank Simon Guérard for critically reading through the manuscript. This work is dedicated to the memory of professor Bent Rolstad who passed away July 2015, and who played a central part in work on bone marrow transplantation and aGvHD models in the rat.

\section{FUNDING}

The work of the authors was supported by the European Union grant FP7-PEOPLE-2012-ITN-315963 (CELLEUROPE).

10. Barnes DW, Loutit JF. Treatment of murine leukaemia with $\mathrm{x}$-rays and homologous bone marrow. II. Br J Haematol (1957) 3:241-52. doi:10.1111/ j.1365-2141.1957.tb05793.x

11. Thomas ED, Lochte HL Jr, Cannon JH, Sahler OD, Ferrebee JW. Supralethal whole body irradiation and isologous marrow transplantation in man. J Clin Invest (1959) 38:1709-16. doi:10.1172/JCI103949

12. Mathe G, Bernard J. [Trial therapy, by x-irradiation followed by the administration of homologous bone marrow cells, of highly-advanced spontaneous leukemia in AK mice]. Bull Assoc Fr Etud Cancer (1958) 45:289-300.

13. Simonsen $M$. The impact on the developing embryo and newborn animal of adult homologous cells. Acta Pathol Microbiol Scand (1957) 40:480-500. doi:10.1111/j.1600-0463.2007.apm_698a.x

14. Billingham RE. Studies on the reaction of injected homologous lymphoid tissue cells against the host. Ann N Y Acad Sci (1958) 73:782-8. doi:10.1111/ j.1749-6632.1959.tb40857.x

15. Trentin JJ. Mortality and skin transplantability in $\mathrm{x}$-irradiated mice receiving isologous, homologous or heterologous bone marrow. Proc Soc Exp Biol Med (1956) 92:688-93. doi:10.3181/00379727-92-22582

16. Barnes DW, Ilbery PL, Loutit JF. Avoidance of secondary disease in radiation chimaeras. Nature (1958) 181:488. doi:10.1038/181488a0

17. Ilbery PL, Koller PC, Loutit JF. Immunological characteristics of radiation chimaeras. J Natl Cancer Inst (1958) 20:1051-89.

18. Schwartz EE, Upton AC, Congdon CC. A fatal reaction caused by implantation of adult parental spleen tissue in irradiated F1 mice. Proc Soc Exp Biol Med (1957) 96:797-800. doi:10.3181/00379727-96-23612 
19. Woodruff MF, Sparrow M. Further observation on the induction of tolerance of skin homografts in rats. Transplant Bull (1957) 4:157-9.

20. Egdahl RH, Roller FR, Swanson RL, Varco RL. Acquired tolerance to homografts and heterografts in the rat. Ann N Y Acad Sci (1958) 73:842-7. doi:10.1111/j.1749-6632.1959.tb40864.x

21. Nakic B, Silobrcic V. Tolerance of skin homografts related to fatal disease in separated rat parabionts. Nature (1958) 182:264-5. doi:10.1038/182264a0

22. Finerty JC. Parabiosis in physiological studies. Physiol Rev (1952) 32:277-302.

23. Harris PF, Harris RS, Kugler JH. Studies of the leucocyte compartment in guinea-pig bone marrow after acute haemorrhage and severe hypoxia: evidence for a common stem-cell. Br J Haematol (1966) 12:419-32. doi:10.1111/j.1365-2141.1966.tb05651.x

24. van Dicke KAHJI, van Bekkum DW. The selective elimination of immunologically competent cells from bone marrow and lymphatic cell mixtures. II. Mouse spleen cell fractionation on a discontinuous albumin gradient. Transplantation (1968) 6:562-70. doi:10.1097/00007890-196807000-00009

25. Boak JL, Fox M, Wilson RE. Activity of lymphoid tissues from antilymphocyteserum-treated mice. Lancet (1967) 1:750-2. doi:10.1016/0140-6736(67) 91366-9

26. van BekkumDW, Balner H,DickeKA, van den BergFG, Prinsen GH, Hollander CF. The effect of pretreatment of allogeneic bone marrow graft recipients with antilymphocytic serum on the acute graft-versus-host reaction in monkeys. Transplantation (1972) 13:400-7. doi:10.1097/00007890-197204000-00007

27. Vallera DA, Soderling CC, Carlson GJ, Kersey JH. Bone marrow transplantation across major histocompatibility barriers in mice. Effect of elimination of $\mathrm{T}$ cells from donor grafts by treatment with monoclonal Thy-1.2 plus complement or antibody alone. Transplantation (1981) 31:218-22. doi:10.1097/00007890-198103000-00015

28. Rayfield LS, Brent L. Tolerance, immunocompetence, and secondary disease in fully allogeneic radiation chimeras. Transplantation (1983) 36:183-9. doi:10.1097/00007890-198308000-00015

29. Lonai P, Eliraz A, Wekerle H, Feldman M. Depletion of specific graft-versus-host reactivity following adsorption of nonsensitized lymphocytes on allogeneic fibroblasts. Transplantation (1973) 15:368-74. doi:10.1097/00007890-197304000-00004

30. Blazar BR, Carroll SF, Vallera DA. Prevention of murine graft-versus-host disease and bone marrow alloengraftment across the major histocompatibility barrier after donor graft preincubation with anti-LFA1 immunotoxin. Blood (1991) 78:3093-102.

31. Weiden PL, Storb R, Tsoi MS, Graham TC, Lerner KG, Thomas ED. Infusion of donor lymphocytes into stable canine radiation chimeras: implications for mechanism of transplantation tolerance. J Immunol (1976) 116:1212-9.

32. Sykes M, Sheard MA, Sachs DH. Graft-versus-host-related immunosuppression is induced in mixed chimeras by alloresponses against either host or donor lymphohematopoietic cells. J Exp Med (1988) 168:2391-6. doi:10.1084/jem.168.6.2391

33. Tutschka PJ, Hess AD, Beschorner WE, Santos GW. Suppressor cells in transplantation tolerance. I. Suppressor cells in the mechanism of tolerance in radiation chimeras. Transplantation (1981) 32:203-9. doi:10.1097/ 00007890-198109000-00005

34. Kolb HJ, Günther W, Schumm M, Holler E, Wilmanns W, Thierfelder S. Adoptive immunotherapy in canine chimeras. Transplantation (1997) 63:430-6. doi:10.1097/00007890-199702150-00017

35. Epstein RB, Storb R, Ragde H, Thomas ED. Cytotoxic typing antisera for marrow grafting in littermate dogs. Transplantation (1968) 6:45-58. doi:10.1097/00007890-196801000-00005

36. Storb R, Rudolph RH, Thomas ED. Marrow grafts between canine siblings matched by serotyping and mixed leukocyte culture. J Clin Invest (1971) 50:1272-5. doi:10.1172/JCI106605

37. Storb R, Rudolph RH, Kolb HJ, Graham TC, Mickelson E, Erickson V, et al. Marrow grafts between DL-A-matched canine littermates. Transplantation (1973) 15:92-100. doi:10.1097/00007890-197301000-00014

38. Halle-Pannenko O, Pritchard LL, Motta R, Mathe G. Non-H-2 antigens can induce high GVH mortality in adult recipients of normal cells. Biomedicine (1978) 29:253-5.

39. Hamilton BL, Bevan MJ, Parkman R. Anti-recipient cytotoxic T lymphocyte precursors are present in the spleens of mice with acute graft versus host disease due to minor histocompatibility antigens. J Immunol (1981) 126:621-5.
40. Cosgrove GE, Davis ML, Congdon CC. The effect of presensitization of parental donors on graft-versus-host disease in irradiated $\mathrm{F} 1$ hybrid mice. Proc Soc Exp Biol Med (1971) 138:210-2. doi:10.3181/00379727-138-35864

41. Abdollahi A, Li M, Ping G, Plathow C, Domhan S, Kiessling F, et al. Inhibition of platelet-derived growth factor signaling attenuates pulmonary fibrosis. J Exp Med (2005) 201:925-35. doi:10.1084/jem.20041393

42. Korngold R, Sprent J. Lethal graft-versus-host disease after bone marrow transplantation across minor histocompatibility barriers in mice. Prevention by removing mature T cells from marrow. J Exp Med (1978) 148:1687-98. doi:10.1084/jem.148.6.1687

43. Berger M, Wettstein PJ, Korngold R. T cell subsets involved in lethal graft-versus-host disease directed to immunodominant minor histocompatibility antigens. Transplantation (1994) 57:1095-102. doi:10.1097/00007890199404150-00019

44. Qian L, Wu Z, Shen J. Advances in the treatment of acute graft-versus-host disease. J Cell Mol Med (2013) 17:966-75. doi:10.1111/jcmm.12093

45. Higo S, Shimizu A, Masuda Y, Nagasaka S, Kajimoto Y, Kanzaki G, et al. Acute graft-versus-host disease of the kidney in allogeneic rat bone marrow transplantation. PLoS One (2014) 9:e115399. doi:10.1371/journal.pone.0115399

46. Nagler RM, Laufer D, Nagler A. Parotid gland dysfunction in a murine model of acute graft versus host disease [aGVHD]. Head Neck (1998) 20:58-62. doi:10.1002/(SICI)1097-0347(199801)20:1<58::AID-HED9>3.3.CO;2-P

47. Hanada H, Ohno J, Seno K, Ota N, Taniguchi K. Dynamic changes in cellsurface expression of mannose in the oral epithelium during the development of graft-versus-host disease of the oral mucosa in rats. BMC Oral Health (2014) 14:5. doi:10.1186/1472-6831-14-5

48. Peszkowski MJ, Fujiwara K, Warfvinge G, Larsson A. Experimental graft versus host disease in the (BN x LEW) F1 rat hybrid: an immunohistochemical study of early disease in oral mucosa. Oral Dis (1996) 2:2-10. doi:10.1111/ j.1601-0825.1996.tb00196.x

49. Dertschnig S, Hauri-Hohl MM, Vollmer M, Hollander GA, Krenger W. Impaired thymic expression of tissue-restricted antigens licenses the de novo generation of autoreactive CD4+ T cells in acute GVHD. Blood (2015) 125:2720-3. doi:10.1182/blood-2014-08-597245

50. Thepot S, Zhou J, Perrot A, Robin M, Xhaard A, de Latour RP, et al. The graft-versus-leukemia effect is mainly restricted to NIH-defined chronic graft-versus-host disease after reduced intensity conditioning before allogeneic stem cell transplantation. Leukemia (2010) 24:1852-8. doi:10.1038/ leu.2010.187

51. Baird K, Pavletic SZ. Chronic graft versus host disease. Curr Opin Hematol (2006) 13:426-35. doi:10.1097/01.moh.0000245689.47333.ff

52. Panoskaltsis-Mortari A, Lacey DL, Vallera DA, Blazar BR. Keratinocyte growth factor administered before conditioning ameliorates graft-versushost disease after allogeneic bone marrow transplantation in mice. Blood (1998) 92:3960-7.

53. van Leeuwen L, Guiffre A, Atkinson K, Rainer SP, Sewell WA. A two-phase pathogenesis of graft-versus-host disease in mice. Bone Marrow Transplant (2002) 29:151-8. doi:10.1038/sj.bmt.1703328

54. Blaser BW, Roychowdhury S, Kim DJ, Schwind NR, Bhatt D, Yuan W, et al. Donor-derived IL-15 is critical for acute allogeneic graft-versus-host disease. Blood (2005) 105:894-901. doi:10.1182/blood-2004-05-1687

55. Fowler DH, Breglio J, Nagel G, Eckhaus MA, Gress RE. Allospecific CD8+ $\mathrm{Tc1}$ and Tc2 populations in graft-versus-leukemia effect and graft-versushost disease. J Immunol (1996) 157:4811-21.

56. Hildebrandt GC, Olkiewicz KM, Corrion LA, Chang Y, Clouthier SG, Liu C, et al. Donor-derived TNF-alpha regulates pulmonary chemokine expression and the development of idiopathic pneumonia syndrome after allogeneic bone marrow transplantation. Blood (2004) 104:586-93. doi:10.1182/ blood-2003-12-4259

57. Kanamaru A, Okamoto T, Matsuda K, Hara H, Nagai K. Elevation of erythroid colony-stimulating activity in the serum of mice with graft-versus-host disease. Exp Hematol (1984) 12:763-7.

58. Krenger W, Rossi S, Hollander GA. Apoptosis of thymocytes during acute graft-versus-host disease is independent of glucocorticoids. Transplantation (2000) 69:2190-3. doi:10.1097/00007890-200005270-00040

59. Rolink AG, Pals ST, Gleichmann E. Allosuppressor and allohelper T cells in acute and chronic graft-vs.-host disease. II. F1 recipients carrying mutations at H-2K and/or I-A. J Exp Med (1983) 157:755-71. doi:10.1084/jem.157.2.755 
60. Sprent J, Schaefer M, Lo D, Korngold R. Properties of purified T cell subsets. II. In vivo responses to class I vs. class II H-2 differences. J Exp Med (1986) 163:998-1011. doi:10.1084/jem.163.4.998

61. Eyrich M, Burger G, Marquardt K, Budach W, Schilbach K, Niethammer D, et al. Sequential expression of adhesion and costimulatory molecules in graft-versus-host disease target organs after murine bone marrow transplantation across minor histocompatibility antigen barriers. Biol Blood Marrow Transplant (2005) 11:371-82. doi:10.1016/j.bbmt.2005.02.002

62. Korngold R. Lethal graft-versus-host disease in mice directed to multiple minor histocompatibility antigens: features of $\mathrm{CD} 8+$ and $\mathrm{CD} 4+\mathrm{T}$ cell responses. Bone Marrow Transplant (1992) 9:355-64.

63. Zhang Y, Joe G, Hexner E, Zhu J, Emerson SG. Alloreactive memory T cells are responsible for the persistence of graft-versus-host disease. J Immunol (2005) 174:3051-8. doi:10.4049/jimmunol.174.5.3051

64. Okayama J, Ko S, Kanehiro H, Kanokogi H, Hisanaga M, Ohashi K, et al. Bone marrow chimerism and tolerance induced by single-dose cyclophosphamide. J Surg Res (2004) 120:102-10. doi:10.1016/j.jss.2004.01.011

65. Zinöcker S, Wang MY, Rolstad B, Vaage JT. Mesenchymal stromal cells fail to alleviate experimental graft-versus-host disease in rats transplanted with major histocompatibility complex-mismatched bone marrow. Scand J Immunol (2012) 76:464-70. doi:10.1111/j.1365-3083.2012.02758.x

66. Aksu AE, Horibe E, Sacks J, Ikeguchi R, Breitinger J, Scozio M, et al. Co-infusion of donor bone marrow with host mesenchymal stem cells treats GVHD and promotes vascularized skin allograft survival in rats. Clin Immunol (2008) 127:348-58. doi:10.1016/j.clim.2008.02.003

67. Nestvold JM, Omdal BK, Dai KZ, Martens A, Benestad HB, Vaage JT, et al. A second prophylactic MHC-mismatched bone marrow transplantation protects against rat acute myeloid leukemia (BNML) without lethal graftversus-host disease. Transplantation (2008) 85:102-11. doi:10.1097/01. tp.0000296856.53493.1f

68. Zinöcker S, Sviland L, Dressel R, Rolstad B. Kinetics of lymphocyte reconstitution after allogeneic bone marrow transplantation: markers of graft-versushost disease. J Leukoc Biol (2011) 90:177-87. doi:10.1189/jlb.0211067

69. Clancy J Jr, Chan P, Schurath R. 3H-deoxythymidine incorporation in graftversus-host disease in the Norway rat. II. Autoradiographic studies. Virchows Arch B Cell Pathol (1976) 22:341-52.

70. Zhu ZX, Fan LY, Wang Q. Simultaneous blockade of costimulatory signals CD28-CD80 and CD40-CD154 combined with monoclonal antibody against CD25 induced a stable chimerism and tolerance without graft-versus-host disease in rat. Eur Surg Res (2011) 46:109-17. doi:10.1159/000323011

71. Zhou S, Ueta H, Xu XD, Shi C, Matsuno K. Predominant donor CD103+CD8+ T cell infiltration into the gut epithelium during acute GvHD: a role of gut lymph nodes. Int Immunol (2008) 20:385-94. doi:10.1093/intimm/dxm153

72. Jäger MD, Liu JY, Timrott KF, Popp FC, Stoeltzing O, Lang SA, et al. Sirolimus promotes tolerance for donor and recipient antigens after MHC class II disparate bone marrow transplantation in rats. Exp Hematol (2007) 35:164-70. doi:10.1016/j.exphem.2006.08.018

73. Sasatomi K, Sakisaka S, Kawaguchi T, Hanada S, Taniguchi E, Koga H, et al. Cholestasis in a rat model of graft-versus-host disease is accompanied by alteration of the expression and distribution of tight-junction-associated proteins. Int J Mol Med (2005) 15:431-6. doi:10.3892/ijmm.15.3.431

74. Wolff D, Frei E, Hofmeister N, Steiner B, Kleine HD, Junghanss C, et al. Methotrexate-albumin and aminopterin-albumin effectively prevent experimental acute graft-versus-host disease. Transplantation (2006) 82:527-33. doi:10.1097/01.tp.0000229451.40286.64

75. Ohajekwe OA, Hardy MA, Oluwole SF. Prevention of graft-versus-host disease and the induction of transplant tolerance by low-dose UV-B irradiation of BM cells combined with cyclosporine immunosuppression. Transplantation (1995) 60:1510-6. doi:10.1097/00007890-199560120-00024

76. Fujino M, Zhu P, Kitazawa Y, Chen JM, Zhuang J, Li XK. Mesenchymal stem cells attenuate rat graft-versus-host disease. Methods Mol Biol (2014) 1213:341-53. doi:10.1007/978-1-4939-1453-1_28

77. Clancy J Jr, Mauser L, Chapman AL. Level and temporal pattern of naturally cytolytic cells during acute Graft-versus-Host Disease (GVHD) in the rat. Cell Immunol (1983) 79:1-10. doi:10.1016/0008-8749(83)90045-X

78. Goral J, Mathews HL, Clancy J Jr. Antibodies specific for the 70-kDa heatshock protein parallel the development of acute graft-versus-host disease in (DA x LEW)F1 rats. Clin Immunol Immunopathol (1995) 75:147-53. doi:10.1006/clin.1995.1064
79. Kimura T, Enosawa S, Kamada N, Kobayashi E, Toyama N, Doy M, et al. Evidence that the elevation of soluble MHC class I antigens in the serum precedes the onset of graft-versus-host disease and is correlated with the severity of the disease in rats. Transpl Immunol (1995) 3:299-304. doi:10.1016/0966-3274(95)80015-8

80. Kobayashi E, Enosawa S, Fujimura A, Kamada N, Suzuki S. Timing of lymphocyte transfusion and portal clamping for the development of lethal graftversus-host disease in the rat. Surg Today (1998) 28:1036-41. doi:10.1007/ BF02483957

81. Vaidya S, Wang CC, Roorda C, Billings A, Rajaraman S, Fish JC. Prevention of graft-versus-host disease by intrathymic injection of recipient-type splenocytes into donor. Transplantation (1996) 62:1366-8. doi:10.1097/00007890-199611150-00035

82. Nestel FP, Price KS, Seemayer TA, Lapp WS. Macrophage priming and lipopolysaccharide-triggered release of tumor necrosis factor alpha during graft-versus-host disease. J Exp Med (1992) 175:405-13. doi:10.1084/ jem.175.2.405

83. Hill GR, Crawford JM, Cooke KR, Brinson YS, Pan L, Ferrara JL. Total body irradiation and acute graft-versus-host disease: the role of gastrointestinal damage and inflammatory cytokines. Blood (1997) 90:3204-13.

84. Cooke KR, Gerbitz A, Crawford JM, Teshima T, Hill GR, Tesolin A, et al. LPS antagonism reduces graft-versus-host disease and preserves graft-versusleukemia activity after experimental bone marrow transplantation. J Clin Invest (2001) 107:1581-9. doi:10.1172/JCI12156

85. Shlomchik WD, Couzens MS, Tang CB, McNiff J, Robert ME, Liu J, et al. Prevention of graft versus host disease by inactivation of host antigenpresenting cells. Science (1999) 285:412-5. doi:10.1126/science.285.5426.412

86. Hill GR. Inflammation and bone marrow transplantation. Biol Blood Marrow Transplant (2009) 15:139-41. doi:10.1016/j.bbmt.2008.11.008

87. Yu C, Storb R, Mathey B, Deeg HJ, Schuening FG, Graham TC, et al. DLAidentical bone marrow grafts after low-dose total body irradiation: effects of high-dose corticosteroids and cyclosporine on engraftment. Blood (1995) $86: 4376-81$.

88. Xun CQ, Thompson JS, Jennings CD, Brown SA, Widmer MB. Effect of total body irradiation, busulfan-cyclophosphamide, or cyclophosphamide conditioning on inflammatory cytokine release and development of acute and chronic graft-versus-host disease in H-2-incompatible transplanted SCID mice. Blood (1994) 83:2360-7.

89. van Bekkum DW, Roodenburg J, Heidt PJ, van der Waaij D. Mitigation of secondary disease of allogeneic mouse radiation chimeras by modification of the intestinal microflora. J Natl Cancer Inst (1974) 52:401-4.

90. Jones JM, Wilson R, Bealmear PM. Mortality and gross pathology of secondary disease in germfree mouse radiation chimeras. Radiat Res (1971) 45:577-88. doi:10.2307/3573066

91. Petersen FB, Buckner CD, Clift RA, Nelson N, Counts GW, Meyers JD, et al. Infectious complications in patients undergoing marrow transplantation: a prospective randomized study of the additional effect of decontamination and laminar air flow isolation among patients receiving prophylactic systemic antibiotics. Scand J Infect Dis (1987) 19:559-67. doi:10.3109/00365548709032423

92. Russell JA, Chaudhry A, Booth K, Brown C, Woodman RC, Valentine K, et al. Early outcomes after allogeneic stem cell transplantation for leukemia and myelodysplasia without protective isolation: a 10-year experience. Biol Blood Marrow Transplant (2000) 6:109-14. doi:10.1016/S1083-8791(00)70073-5

93. Heimesaat MM, Nogai A, Bereswill S, Plickert R, Fischer A, Loddenkemper C, et al. MyD88/TLR9 mediated immunopathology and gut microbiota dynamics in a novel murine model of intestinal graft-versus-host disease. Gut (2010) 59:1079-87. doi:10.1136/gut.2009.197434

94. Atarashi K, Tanoue T, Oshima K, Suda W, Nagano Y, Nishikawa H, et al. Treg induction by a rationally selected mixture of Clostridia strains from the human microbiota. Nature (2013) 500:232-6. doi:10.1038/nature12331

95. Jenq RR, Ubeda C, Taur Y, Menezes CC, Khanin R, Dudakov JA, et al. Regulation of intestinal inflammation by microbiota following allogeneic bone marrow transplantation. JExp Med (2012) 209:903-11. doi:10.1084/ jem.20112408

96. Bollyky PL, Evanko SP, Wu RP, Potter-Perigo S, Long SA, Kinsella B, et al. Th1 cytokines promote T-cell binding to antigen-presenting cells via enhanced hyaluronan production and accumulation at the immune synapse. Cell Mol Immunol (2010) 7:211-20. doi:10.1038/cmi.2010.9 
97. Murai M, Yoneyama H, Ezaki T, Suematsu M, Terashima Y, Harada A, et al. Peyer's patch is the essential site in initiating murine acute and lethal graftversus-host reaction. Nat Immunol (2003) 4:154-60. doi:10.1038/ni879

98. Anderson BE, McNiff J, Yan J, Doyle H, Mamula M, Shlomchik MJ, et al. Memory CD4+ T cells do not induce graft-versus-host disease. J Clin Invest (2003) 112:101-8. doi:10.1172/JCI17601

99. Chen BJ, Cui X, Sempowski GD, Liu C, Chao NJ. Transfer of allogeneic CD62L- memory T cells without graft-versus-host disease. Blood (2004) 103:1534-41. doi:10.1182/blood-2003-08-2987

100. Yi T, Chen Y, Wang L, Du G, Huang D, Zhao D, et al. Reciprocal differentiation and tissue-specific pathogenesis of Th1, Th2, and Th17 cells in graft-versushost disease. Blood (2009) 114:3101-12. doi:10.1182/blood-2009-05-219402

101. Burman AC, Banovic T, Kuns RD, Clouston AD, Stanley AC, Morris ES, et al. IFNgamma differentially controls the development of idiopathic pneumonia syndrome and GVHD of the gastrointestinal tract. Blood (2007) 110:1064-72. doi:10.1182/blood-2006-12-063982

102. Iclozan C, Yu Y, Liu C, Liang Y, Yi T, Anasetti C, et al. T helper17 cells are sufficient but not necessary to induce acute graft-versus-host disease. Biol Blood Marrow Transplant (2010) 16:170-8. doi:10.1016/j.bbmt.2009.09.023

103. Yu Y, Wang D, Liu C, Kaosaard K, Semple K, Anasetti C, et al. Prevention of GVHD while sparing GVL effect by targeting Th1 and Th17 transcription factor T-bet and RORgammat in mice. Blood (2011) 118:5011-20. doi:10.1182/blood-2011-03-340315

104. Rowe V, Banovic T, MacDonald KP, Kuns R, Don AL, Morris ES, et al. Host B cells produce IL-10 following TBI and attenuate acute GVHD after allogeneic bone marrow transplantation. Blood (2006) 108:2485-92. doi:10.1182/ blood-2006-04-016063

105. Renkonen R, Wangel A, Hayry P. Bone marrow transplantation in the rat. B lymphocyte activation in acute graft-versus-host disease. Transplantation (1986) 41:290-6. doi:10.1097/00007890-198606000-00007

106. Wysocki CA, Panoskaltsis-Mortari A, Blazar BR, Serody JS. Leukocyte migration and graft-versus-host disease. Blood (2005) 105:4191-9. doi:10.1182/ blood-2004-12-4726

107. Wysocki CA, Burkett SB, Panoskaltsis-Mortari A, Kirby SL, Luster AD, McKinnon K, et al. Differential roles for CCR5 expression on donor T cells during graft-versus-host disease based on pretransplant conditioning. J Immunol (2004) 173:845-54. doi:10.4049/jimmunol.173.2.845

108. Murai M, Yoneyama H, Harada A, Yi Z, Vestergaard C, Guo B, et al. Active participation of CCR5(+)CD8(+) T lymphocytes in the pathogenesis of liver injury in graft-versus-host disease. J Clin Invest (1999) 104:49-57. doi:10.1172/JCI6642

109. Duffner U, Lu B, Hildebrandt GC, Teshima T, Williams DL, Reddy P, et al. Role of CXCR3-induced donor T-cell migration in acute GVHD. Exp Hematol (2003) 31:897-902. doi:10.1016/S0301-472X(03)00198-X

110. Ueha S, Murai M, Yoneyama H, Kitabatake M, Imai T, Shimaoka T, et al. Intervention of MAdCAM-1 or fractalkine alleviates graft-versus-host reaction associated intestinal injury while preserving graft-versus-tumor effects. J Leukoc Biol (2007) 81:176-85. doi:10.1189/jlb.0306231

111. Varona R, Cadenas V, Lozano M, Moreno-Ortiz MC, Kremer L, Martínez-A $\mathrm{C}$, et al. CCR6 regulates the function of alloreactive and regulatory CD4+ $\mathrm{T}$ cells during acute graft-versus-host disease. Leuk Lymphoma (2006) 47:1469-76. doi:10.1080/10428190500513819

112. Teshima T, Ordemann R, Reddy P, Gagin S, Liu C, Cooke KR, et al. Acute graft-versus-host disease does not require alloantigen expression on host epithelium. Nat Med (2002) 8:575-81. doi:10.1038/nm0602-575

113. Theiss-Suennemann J, Jörß K, Messmann JJ, Reichardt SD, Montes-Cobos E, Lühder F, et al. Glucocorticoids attenuate acute graft-versus-host disease by suppressing the cytotoxic capacity of CD8(+) T cells. J Pathol (2015) 235:646-55. doi:10.1002/path.4475

114. Braun MY, Lowin B, French L, Acha-Orbea H, Tschopp J. Cytotoxic T cells deficient in both functional fas ligand and perforin show residual cytolytic activity yet lose their capacity to induce lethal acute graft-versus-host disease. J Exp Med (1996) 183:657-61. doi:10.1084/jem.183.2.657

115. Graubert TA, DiPersio JF, Russell JH, Ley TJ. Perforin/granzyme-dependent and independent mechanisms are both important for the development of graft-versus-host disease after murine bone marrow transplantation. J Clin Invest (1997) 100:904-11. doi:10.1172/JCI119606

116. Maeda Y, Levy RB, Reddy P, Liu C, Clouthier SG, Teshima T, et al. Both perforin and Fas ligand are required for the regulation of alloreactive CD8+
T cells during acute graft-versus-host disease. Blood (2005) 105:2023-7. doi:10.1182/blood-2004-08-3036

117. Ghosh A, Dogan Y, Moroz M, Holland AM, Yim NL, Rao UK, et al. Adoptively transferred TRAIL+ T cells suppress GVHD and augment antitumor activity. J Clin Invest (2013) 123:2654-62. doi:10.1172/JCI66301

118. Storb R, Epstein RB, Graham TC, Thomas ED. Methotrexate regimens for control of graft-versus-host disease in dogs with allogeneic marrow grafts. Transplantation (1970) 9:240-6. doi:10.1097/00007890-197003000-00007

119. Thomas ED, Collins JA, Herman EC Jr, Ferrebee JW. Marrow transplants in lethally irradiated dogs given methotrexate. Blood (1962) 19:217-28.

120. Deeg HJ, Storb R, Weiden PL, Raff RF, Sale GE, Atkinson K, et al. Cyclosporin $\mathrm{A}$ and methotrexate in canine marrow transplantation: engraftment, graftversus-host disease, and induction of intolerance. Transplantation (1982) 34:30-5. doi:10.1097/00007890-198207000-00006

121. Deeg HJ, Storb R, Appelbaum FR, Kennedy MS, Graham TC, Thomas ED. Combined immunosuppression with cyclosporine and methotrexate in dogs given bone marrow grafts from DLA-haploidentical littermates. Transplantation (1984) 37:62-5. doi:10.1097/00007890-198401000-00017

122. Deeg HJ, Storb R, Weiden PL, Graham T, Atkinson K, Thomas ED Cyclosporin-A: effect on marrow engraftment and graft-versus-host disease in dogs. Transplant Proc (1981) 13:402-4.

123. Storb R, Deeg HJ, Pepe M, Appelbaum F, Anasetti C, Beatty P, et al. Methotrexate and cyclosporine versus cyclosporine alone for prophylaxis of graft-versus-host disease in patients given HLA-identical marrow grafts for leukemia: long-term follow-up of a controlled trial. Blood (1989) 73:1729-34.

124. Sorror ML, Leisenring W, Deeg HJ, Martin PJ, Storb R. Twenty-year follow-up of a controlled trial comparing a combination of methotrexate plus cyclosporine with cyclosporine alone for prophylaxis of graft-versus-host disease in patients administered HLA-identical marrow grafts for leukemia. Biol Blood Marrow Transplant (2005) 11:814-5. doi:10.1016/j.bbmt. 2005.05.016

125. Sun J, Dotti G, Huye LE, Foster AE, Savoldo B, Gramatges MM, et al. T cells expressing constitutively active Akt resist multiple tumor-associated inhibitory mechanisms. Mol Ther (2010) 18:2006-17. doi:10.1038/mt.2010.185

126. Ruutu T, Gratwohl A, de Witte T, Afanasyev B, Apperley J, Bacigalupo A, et al. Prophylaxis and treatment of GVHD: EBMT-ELN working group recommendations for a standardized practice. Bone Marrow Transplant (2014) 49:168-73. doi:10.1038/bmt.2013.107

127. Piguet PF, Grau GE, Allet B, Vassalli P. Tumor necrosis factor/cachectin is an effector of skin and gut lesions of the acute phase of graft-vs.-host disease. J Exp Med (1987) 166:1280-9. doi:10.1084/jem.166.5.1280

128. Cooke KR, Hill GR, Crawford JM, Bungard D, Brinson YS, Delmonte J Jr, et al. Tumor necrosis factor-alpha production to lipopolysaccharide stimulation by donor cells predicts the severity of experimental acute graft-versus-host disease. J Clin Invest (1998) 102:1882-91. doi:10.1172/JCI4285

129. Tawara I, Koyama M, Liu C, Toubai T, Thomas D, Evers R, et al. Interleukin-6 modulates graft-versus-host responses after experimental allogeneic bone marrow transplantation. Clin Cancer Res (2011) 17:77-88. doi:10.1158/10780432.CCR-10-1198

130. Givon T, Revel M, Slavin S. Potential use of interleukin-6 in bone marrow transplantation: effects of recombinant human interleukin- 6 after syngeneic and semiallogeneic bone marrow transplantation in mice. Blood (1994) 83:1690-7.

131. Chen X, Das R, Komorowski R, Beres A, Hessner MJ, Mihara M, et al. Blockade of interleukin-6 signaling augments regulatory T-cell reconstitution and attenuates the severity of graft-versus-host disease. Blood (2009) 114:891-900. doi:10.1182/blood-2009-01-197178

132. Drobyski WR, Pasquini M, Kovatovic K, Palmer J, Douglas Rizzo J, Saad A, et al. Tocilizumab for the treatment of steroid refractory graft-versus-host disease. Biol Blood Marrow Transplant (2011) 17:1862-8. doi:10.1016/j. bbmt.2011.07.001

133. Sykes M, Abraham VS, Harty MW, Pearson DA. IL-2 reduces graft-versushost disease and preserves a graft-versus-leukemia effect by selectively inhibiting CD4+ T cell activity. J Immunol (1993) 150:197-205.

134. Perol L, Martin GH, Maury S, Cohen JL, Piaggio E. Potential limitations of IL-2 administration for the treatment of experimental acute graft-versus-host disease. Immunol Lett (2014) 162:173-84. doi:10.1016/j.imlet.2014.10.027

135. Shin HJ, Baker J, Leveson-Gower DB, Smith AT, Sega EI, Negrin RS. Rapamycin and IL-2 reduce lethal acute graft-versus-host disease associated 
with increased expansion of donor type CD4+CD25+Foxp3+ regulatory T cells. Blood (2011) 118:2342-50. doi:10.1182/blood-2010-10-313684

136. Zenewicz LA, Flavell RA. Recent advances in IL-22 biology. Int Immunol (2011) 23:159-63. doi:10.1093/intimm/dxr001

137. Sanos SL, Vonarbourg C, Mortha A, Diefenbach A. Control of epithelial cell function by interleukin-22-producing RORgammat+ innate lymphoid cells. Immunology (2011) 132:453-65. doi:10.1111/j.1365-2567.2011.03410.x

138. Hanash AM, Dudakov JA, Hua G, O'Connor MH, Young LF, Singer NV, et al. Interleukin-22 protects intestinal stem cells from immune-mediated tissue damage and regulates sensitivity to graft versus host disease. Immunity (2012) 37:339-50. doi:10.1016/j.immuni.2012.05.028

139. Lamarthee B, Malard F, Gamonet C, Bossard C, Couturier M, et al. Donor interleukin-22 and host type I interferon signaling pathway participate in intestinal graft-versus-host disease via STAT1 activation and CXCL10. Mucosal Immunol (2015) 9:309-21. doi:10.1038/mi.2015.61

140. He S, Cao Q, Qiu Y, Mi J, Zhang JZ, Jin M, et al. A new approach to the blocking of alloreactive $\mathrm{T}$ cell-mediated graft-versus-host disease by in vivo administration of anti-CXCR3 neutralizing antibody. J Immunol (2008) 181:7581-92. doi:10.4049/jimmunol.181.11.7581

141. Wysocki CA, Jiang Q, Panoskaltsis-Mortari A, Taylor PA, McKinnon KP, Su $\mathrm{L}$, et al. Critical role for CCR5 in the function of donor CD4+CD25+ regulatory T cells during acute graft-versus-host disease. Blood (2005) 106:3300-7. doi:10.1182/blood-2005-04-1632

142. Hasegawa H, Inoue A, Kohno M, Lei J, Miyazaki T, Yoshie O, et al. Therapeutic effect of CXCR3-expressing regulatory T cells on liver, lung and intestinal damages in a murine acute GVHD model. Gene Ther (2008) 15:171-82. doi:10.1038/sj.gt.3303051

143. Miklos S, Mueller G, Chang Y, Bouazzaoui A, Spacenko E, Schubert TE, et al. Preventive usage of broad spectrum chemokine inhibitor NR58-3.14.3 reduces the severity of pulmonary and hepatic graft-versus-host disease. Int J Hematol (2009) 89:383-97. doi:10.1007/s12185-009-0272-y

144. Blazar BR, Sharpe AH, Taylor PA, Panoskaltsis-Mortari A, Gray GS, Korngold $\mathrm{R}$, et al. Infusion of anti-B7.1 (CD80) and anti-B7.2 (CD86) monoclonal antibodies inhibits murine graft-versus-host disease lethality in part via direct effects on CD4+ and CD8+ T cells. J Immunol (1996) 157:3250-9.

145. Yu XZ, Bidwell SJ, Martin PJ, Anasetti C. CD28-specific antibody prevents graft-versus-host disease in mice. J Immunol (2000) 164:4564-8. doi:10.4049/ jimmunol.164.9.4564

146. Durie FH, Aruffo A, Ledbetter J, Crassi KM, Green WR, Fast LD, et al. Antibody to the ligand of $\mathrm{CD} 40$, gp39, blocks the occurrence of the acute and chronic forms of graft-vs-host disease. J Clin Invest (1994) 94:1333-8. doi:10.1172/JCI117453

147. Hargreaves RE, Monk NJ, Jurcevic S. Selective depletion of activated T cells: the CD40L-specific antibody experience. Trends Mol Med (2004) 10:130-5. doi:10.1016/j.molmed.2004.01.009

148. Taylor PA, Friedman TM, Korngold R, Noelle RJ, Blazar BR. Tolerance induction of alloreactive $\mathrm{T}$ cells via ex vivo blockade of the CD40:CD40L costimulatory pathway results in the generation of a potent immune regulatory cell. Blood (2002) 99:4601-9. doi:10.1182/blood.V99.12.4601

149. Tittle TV, Weinberg AD, Steinkeler CN, Maziarz RT. Expression of the T-cell activation antigen, OX-40, identifies alloreactive T cells in acute graft-versushost disease. Blood (1997) 89:4652-8.

150. Blazar BR, Sharpe AH, Chen AI, Panoskaltsis-Mortari A, Lees C, Akiba H, et al. Ligation of OX40 (CD134) regulates graft-versus-host disease (GVHD) and graft rejection in allogeneic bone marrow transplant recipients. Blood (2003) 101:3741-8. doi:10.1182/blood-2002-10-3048

151. Nozawa K, Ohata J, Sakurai J, Hashimoto H, Miyajima H, Yagita H, et al. Preferential blockade of $\mathrm{CD} 8(+) \mathrm{T}$ cell responses by administration of anti-CD137 ligand monoclonal antibody results in differential effect on development of murine acute and chronic graft-versus-host diseases. J Immunol (2001) 167:4981-6. doi:10.4049/jimmunol.167.9.4981

152. Taylor PA, Panoskaltsis-Mortari A, Freeman GJ, Sharpe AH, Noelle RJ, Rudensky AY, et al. Targeting of inducible costimulator (ICOS) expressed on alloreactive $\mathrm{T}$ cells down-regulates graft-versus-host disease (GVHD) and facilitates engraftment of allogeneic bone marrow (BM). Blood (2005) 105:3372-80. doi:10.1182/blood-2004-10-3869

153. Xu Y, Flies AS, Flies DB, Zhu G, Anand S, Flies SJ, et al. Selective targeting of the LIGHT-HVEM costimulatory system for the treatment of graft- versus-host disease. Blood (2007) 109:4097-104. doi:10.1182/blood-200609-047332

154. Karimi MA, Bryson JL, Richman LP, Fesnak AD, Leichner TM, Satake A, et al. NKG2D expression by CD8+ T cells contributes to GVHD and GVT effects in a murine model of allogeneic HSCT. Blood (2015) 125:3655-63. doi:10.1182/blood-2015-02-629006

155. Nabekura T, Shibuya K, Takenaka E, Kai H, Shibata K, Yamashita Y, et al. Critical role of DNAX accessory molecule-1 (DNAM-1) in the development of acute graft-versus-host disease in mice. Proc Natl Acad Sci U S A (2010) 107:18593-8. doi:10.1073/pnas.1005582107

156. Blazar BR, Levy RB, Mak TW, Panoskaltsis-Mortari A, Muta H, Jones M, et al. CD30/CD30 ligand (CD153) interaction regulates CD4+ T cell-mediated graft-versus-host disease. J Immunol (2004) 173:2933-41. doi:10.4049/ jimmunol.173.5.2933

157. Ringdén O, Uzunel M, Rasmusson I, Remberger M, Sundberg B, Lönnies $\mathrm{H}$, et al. Mesenchymal stem cells for treatment of therapy-resistant graftversus-host disease. Transplantation (2006) 81:1390-7. doi:10.1097/01. tp.0000214462.63943.14

158. Méndez-Ferrer S, Michurina TV, Ferraro F, Mazloom AR, Macarthur BD, Lira SA, et al. Mesenchymal and haematopoietic stem cells form a unique bone marrow niche. Nature (2010) 466:829-34. doi:10.1038/nature09262

159. Li MQ, Hou XF, Shao J, Tang CL, Li DJ. The DSCs-expressed CD82 controls the invasiveness of trophoblast cells via integrinbeta1/MAPK/MAPK3/1 signaling pathway in human first-trimester pregnancy. Biol Reprod (2010) 82:968-79. doi:10.1095/biolreprod.109.080739

160. Mattar P, Bieback K. Comparing the immunomodulatory properties of bone marrow, adipose tissue, and birth-associated tissue mesenchymal stromal cells. Front Immunol (2015) 6:560. doi:10.3389/fimmu.2015.00560

161. Ball LM, Bernardo ME, Roelofs H, van Tol MJ, Contoli B, Zwaginga JJ, et al. Multiple infusions of mesenchymal stromal cells induce sustained remission in children with steroid-refractory, grade III-IV acute graft-versus-host disease. Br J Haematol (2013) 163:501-9. doi:10.1111/bjh.12545

162. Badillo AT, Peranteau WH, Heaton TE, Quinn C, Flake AW. Murine bone marrow derived stromal progenitor cells fail to prevent or treat acute graft-versus-host disease. Br J Haematol (2008) 141:224-34. doi:10.1111/ j.1365-2141.2008.07040.x

163. Mielcarek M, Storb R, Georges GE, Golubev L, Nikitine A, Hwang B, et al. Mesenchymal stromal cells fail to prevent acute graft-versus-host disease and graft rejection after dog leukocyte antigen-haploidentical bone marrow transplantation. Biol Blood Marrow Transplant (2011) 17:214-25. doi:10.1016/j.bbmt.2010.08.015

164. Sudres M, Norol F, Trenado A, Grégoire S, Charlotte F, Levacher B, et al. Bone marrow mesenchymal stem cells suppress lymphocyte proliferation in vitro but fail to prevent graft-versus-host disease in mice. J Immunol (2006) 176:7761-7. doi:10.4049/jimmunol.176.12.7761

165. Li H, Guo Z, Jiang X, Zhu H, Li X, Mao N. Mesenchymal stem cells alter migratory property of $\mathrm{T}$ and dendritic cells to delay the development of murine lethal acute graft-versus-host disease. Stem Cells (2008) 26:2531-41. doi:10.1634/stemcells.2008-0146

166. Tisato V, Naresh K, Girdlestone J, Navarrete C, Dazzi F. Mesenchymal stem cells of cord blood origin are effective at preventing but not treating graft-versus-host disease. Leukemia (2007) 21:1992-9. doi:10.1038/sj.leu. 2404847

167. Galipeau J. The mesenchymal stromal cells dilemma - does a negative phase III trial of random donor mesenchymal stromal cells in steroid-resistant graft-versus-host disease represent a death knell or a bump in the road? Cytotherapy (2013) 15:2-8. doi:10.1016/j.jcyt.2012.10.002

168. Tolar J, Villeneuve P, Keating A. Mesenchymal stromal cells for graft-versushost disease. Hum Gene Ther (2011) 22:257-62. doi:10.1089/hum.2011.1104

169. Waterman RS, Tomchuck SL, Henkle SL, Betancourt AM. A new mesenchymal stem cell (MSC) paradigm: polarization into a pro-inflammatory MSC1 or an immunosuppressive MSC2 phenotype. PLoS One (2010) 5:e10088. doi:10.1371/journal.pone.0010088

170. Moll G, Le Blanc K. Engineering more efficient multipotent mesenchymal stromal (stem) cells for systemic delivery as cellular therapy. ISBT Sci Ser (2015) 10:357-65. doi:10.1111/voxs.12133

171. Stephens LA, Mason D. CD25 is a marker for CD4+ thymocytes that prevent autoimmune diabetes in rats, but peripheral $\mathrm{T}$ cells with this function 
are found in both CD25+ and CD25- subpopulations. JImmunol (2000) 165:3105-10. doi:10.4049/jimmunol.165.6.3105

172. Stephens LA, Mottet C, Mason D, Powrie F. Human CD4(+)CD25(+) thymocytes and peripheral $\mathrm{T}$ cells have immune suppressive activity in vitro. Eur J Immunol (2001) 31:1247-54. doi:10.1002/1521-4141(200104)31:4< 1247::AID-IMMU1247>3.0.CO;2-M

173. Itoh M, Takahashi T, Sakaguchi N, Kuniyasu Y, Shimizu J, Otsuka F, et al. Thymus and autoimmunity: production of $\mathrm{CD} 25+\mathrm{CD} 4+$ naturally anergic and suppressive $\mathrm{T}$ cells as a key function of the thymus in maintaining immunologic self-tolerance. J Immunol (1999) 162:5317-26.

174. Fontenot JD, Rasmussen JP, Williams LM, Dooley JL, Farr AG, Rudensky AY. Regulatory $\mathrm{T}$ cell lineage specification by the forkhead transcription factor foxp3. Immunity (2005) 22:329-41. doi:10.1016/j.immuni.2005.01.016

175. Cohen JL, Trenado A, Vasey D, Klatzmann D, Salomon BL. CD4(+)CD25(+) immunoregulatory $\mathrm{T}$ cells: new therapeutics for graft-versus-host disease. J Exp Med (2002) 196:401-6. doi:10.1084/jem.20020090

176. Hoffmann P, Ermann J, Edinger M, Fathman CG, Strober S. Donor-type $\mathrm{CD} 4(+) \mathrm{CD} 25(+)$ regulatory T cells suppress lethal acute graft-versus-host disease after allogeneic bone marrow transplantation. J Exp Med (2002) 196:389-99. doi:10.1084/jem.20020399

177. Ermann J, Hoffmann P, Edinger M, Dutt S, Blankenberg FG, Higgins JP, et al. Only the CD62L+ subpopulation of CD4+CD25+ regulatory T cells protects from lethal acute GVHD. Blood (2005) 105:2220-6. doi:10.1182/ blood-2004-05-2044

178. Taylor PA, Panoskaltsis-Mortari A, Swedin JM, Lucas PJ, Gress RE, Levine BL, et al. L-Selectin(hi) but not the L-selectin(lo) CD4+25+ T-regulatory cells are potent inhibitors of GVHD and BM graft rejection. Blood (2004) 104:3804-12. doi:10.1182/blood-2004-05-1850

179. Fantini MC, Becker C, Monteleone G, Pallone F, Galle PR, Neurath MF. Cutting edge: TGF-beta induces a regulatory phenotype in CD4+CD25$\mathrm{T}$ cells through Foxp3 induction and down-regulation of Smad7. J Immunol (2004) 172:5149-53. doi:10.4049/jimmunol.172.9.5149

180. Koenecke C, Czeloth N, Bubke A, Schmitz S, Kissenpfennig A, Malissen B, et al. Alloantigen-specific de novo-induced Foxp3+ Treg revert in vivo and do not protect from experimental GVHD. Eur J Immunol (2009) 39:3091-6. doi:10.1002/eji.200939432

181. Beres A, Komorowski R, Mihara M, Drobyski WR. Instability of Foxp3 expression limits the ability of induced regulatory $\mathrm{T}$ cells to mitigate graft versus host disease. Clin Cancer Res (2011) 17:3969-83. doi:10.1158/10780432.CCR-10-3347

182. Bucher C, Koch L, Vogtenhuber C, Goren E, Munger M, Panoskaltsis-Mortari A, et al. IL-21 blockade reduces graft-versus-host disease mortality by supporting inducible T regulatory cell generation. Blood (2009) 114:5375-84. doi:10.1182/blood-2009-05-221135

183. Laurence A, Amarnath S, Mariotti J, Kim YC, Foley J, Eckhaus M, et al. STAT3 transcription factor promotes instability of nTreg cells and limits generation of iTreg cells during acute murine graft-versus-host disease. Immunity (2012) 37:209-22. doi:10.1016/j.immuni.2012.05.027

184. Rolstad B, Ford WL. The rapid elimination of allogeneic lymphocytes: relationship to established mechanisms of immunity and to lymphocyte traffic. Immunol Rev (1983) 73:87-113. doi:10.1111/j.1600-065X.1983. tb01080.x

185. Tønnesen B, Rolstad B. In vivo elimination of allogeneic lymphocytes in normal and T-cell-deficient rats. Elimination does not require T cells. Scand J Immunol (1983) 17:303-12. doi:10.1111/j.1365-3083.1983. tb00794.x

186. Cudkowicz G, Stimpfling JH. Hybrid resistance to parental marrow grafts: association with the K region of H-2. Science (1964) 144:1339-40. doi:10.1126/science.144.3624.1339

187. Engh E, Benestad HB, Strøm-Gundersen I, Vaage JT, Bell EB, Rolstad B. Role of classical (RT1.A) and nonclassical (RT1.C) MHC class I regions in natural killer cell-mediated bone marrow allograft rejection in rats. Transplantation (1998) 65:319-24. doi:10.1097/00007890-199802150-00005

188. Engh E, Strøm-Gundersen I, Benestad HB, Rolstad B. Long-term donor chimerism after MHC (RT1) mismatched bone marrow transplantation in the rat: the role of host alloreactive NK cells. Scand J Immunol (2001) 54:198-203. doi:10.1046/j.1365-3083.2001.00929.x

189. Ruggeri L, Capanni M, Urbani E, Perruccio K, Shlomchik WD, Tosti A, et al. Effectiveness of donor natural killer cell alloreactivity in mismatched hematopoietic transplants. Science (2002) 295:2097-100. doi:10.1126/ science. 1068440

190. Huber CM, Doisne JM, Colucci F. IL-12/15/18-preactivated NK cells suppress GvHD in a mouse model of mismatched hematopoietic cell transplantation. Eur J Immunol (2015) 45:1727-35. doi:10.1002/eji.201445200

191. Filipovich AH, Weisdorf D, Pavletic S, Socie G, Wingard JR, Lee SJ, et al. National Institutes of Health consensus development project on criteria for clinical trials in chronic graft-versus-host disease: I. Diagnosis and staging working group report. Biol Blood Marrow Transplant (2005) 11:945-56. doi:10.1016/j.bbmt.2005.09.004

192. Flowers ME, Inamoto Y, Carpenter PA, Lee SJ, Kiem HP, Petersdorf EW, et al. Comparative analysis of risk factors for acute graft-versus-host disease and for chronic graft-versus-host disease according to National Institutes of Health consensus criteria. Blood (2011) 117:3214-9. doi:10.1182/ blood-2010-08-302109

193. Schroeder MA, DiPersio JF. Mouse models of graft-versus-host disease: advances and limitations. Dis Model Mech (2011) 4:318-33. doi:10.1242/ dmm. 006668

194. Shustov A, Nguyen P, Finkelman F, Elkon KB, Via CS. Differential expression of Fas and Fas ligand in acute and chronic graft-versus-host disease: up-regulation of Fas and Fas ligand requires CD8+ T cell activation and IFN-gamma production. J Immunol (1998) 161:2848-55.

195. Morris SC, Cheek RL, Cohen PL, Eisenberg RA. Allotype-specific immunoregulation of autoantibody production by host $\mathrm{B}$ cells in chronic graft-versus host disease. J Immunol (1990) 144:916-22.

196. Wu T, Young JS, Johnston H, Ni X, Deng R, Racine J, et al. Thymic damage, impaired negative selection, and development of chronic graft-versushost disease caused by donor CD4+ and CD8+ T cells. J Immunol (2013) 191:488-99. doi:10.4049/jimmunol.1300657

197. Oliner H, Schwartz R, Dameshek W. Studies in experimental autoimmune disorders. I. Clinical and laboratory features of autoimmunization (runt disease) in the mouse. Blood (1961) 17:20-44.

198. Stastny P, Stembridge VA, Ziff M. Homologous disease in the adult rat, a model for autoimmune disease. I. General features and cutaneous lesions. J Exp Med (1963) 118:635-48. doi:10.1084/jem.118.4.635

199. Lewis RM, Armstrong MY, André-Schwartz J, Muftuoglu A, Beldotti L, Schwartz RS. Chronic allogeneic disease. I. Development of glomerulonephritis. J Exp Med (1968) 128:653-79. doi:10.1084/jem.128.4.653

200. Rappaport H, Khalil A, Halle-Pannenko O, Pritchard L, Dantchev D, Mathé G. Histopathologic sequence of events in adult mice undergoing lethal graft-versus-host reaction developed across $\mathrm{H}-2$ and/or non- $\mathrm{H}-2$ histocompatibility barriers. Am J Pathol (1979) 96:121-42.

201. Beschorner WE, Tutschka PJ, Santos GW. Chronic graft-versus-host disease in the rat radiation chimera. I. Clinical features, hematology, histology, and immunopathology in long-term chimeras. Transplantation (1982) 33:393-9. doi:10.1097/00007890-198204000-00010

202. Jaffee BD, Claman HN. Chronic graft-versus-host disease (GVHD) as a model for scleroderma. I. Description of model systems. Cell Immunol (1983) 77:1-12. doi:10.1016/0008-8749(83)90001-1

203. Claman HN, Jaffee BD, Huff JC, Clark RA. Chronic graft-versus-host disease as a model for scleroderma. II. Mast cell depletion with deposition of immunoglobulins in the skin and fibrosis. Cell Immunol (1985) 94:73-84. doi:10.1016/0008-8749(85)90086-3

204. Allison AC, Denman AM, Barnes RD. Cooperating and controlling functions of thymus-derived lymphocytes in relation to autoimmunity. Lancet (1971) 2:135-40. doi:10.1016/S0140-6736(71)92306-3

205. Fialkow PJ, Gilchrist C, Allison AC. Autoimmunity in chronic graft-versushost disease. Clin Exp Immunol (1973) 13:479-86.

206. Zhang Y, Hexner E, Frank D, Emerson SG. CD4+ T cells generated de novo from donor hemopoietic stem cells mediate the evolution from acute to chronic graft-versus-host disease. J Immunol (2007) 179:3305-14. doi:10.4049/jimmunol.179.5.3305

207. Zhao D, Young JS, Chen YH, Shen E, Yi T, Todorov I, et al. Alloimmune response results in expansion of autoreactive donor CD4+ T cells in transplants that can mediate chronic graft-versus-host disease. J Immunol (2011) 186:856-68. doi:10.4049/jimmunol.1002195

208. Hamilton BL. L3T4-positive T cells participate in the induction of graft-vshost disease in response to minor histocompatibility antigens. J Immunol (1987) 139:2511-5. 
209. Korngold R, Sprent J. Variable capacity of L3T4+ T cells to cause lethal graftversus-host disease across minor histocompatibility barriers in mice. J Exp Med (1987) 165:1552-64. doi:10.1084/jem.165.6.1552

210. Yamashita K, Choi U, Woltz PC, Foster SF, Sneller MC, Hakim FT, et al. Severe chronic graft-versus-host disease is characterized by a preponderance of $\mathrm{CD} 4(+)$ effector memory cells relative to central memory cells. Blood (2004) 103:3986-8. doi:10.1182/blood-2003-09-3286

211. Xystrakis E, Bernard I, Dejean AS, Alsaati T, Druet P, Saoudi A. Alloreactive CD4 T lymphocytes responsible for acute and chronic graft-versus-host disease are contained within the CD45RChigh but not the CD45RClow subset. Eur J Immunol (2004) 34:408-17. doi:10.1002/eji.200324528

212. Tschetter JR, Mozes E, Shearer GM. Progression from acute to chronic disease in a murine parent-into-F1 model of graft-versus-host disease. J Immunol (2000) 165:5987-94. doi:10.4049/jimmunol.165.10.5987

213. Kim J, Kim HJ, Choi WS, Nam SH, Cho HR, Kwon B. Maintenance of CD8+ $\mathrm{T}$-cell anergy by $\mathrm{CD} 4+\mathrm{CD} 25+$ regulatory $\mathrm{T}$ cells in chronic graft-versus-host disease. Exp Mol Med (2006) 38:494-501. doi:10.1038/emm.2006.58

214. Biedermann BC, Sahner S, Gregor M, Tsakiris DA, Jeanneret C, Pober JS, et al. Endothelial injury mediated by cytotoxic T lymphocytes and loss of microvessels in chronic graft versus host disease. Lancet (2002) 359:2078-83. doi:10.1016/S0140-6736(02)08907-9

215. Morris SC, Cheek RL, Cohen PL, Eisenberg RA. Autoantibodies in chronic graft versus host result from cognate T-B interactions. J Exp Med (1990) 171:503-17. doi:10.1084/jem.171.2.503

216. Via CS, Rus V, Nguyen P, Linsley P, Gause WC. Differential effect of CTLA4Ig on murine graft-versus-host disease (GVHD) development: CTLA4Ig prevents both acute and chronic GVHD development but reverses only chronic GVHD. J Immunol (1996) 157:4258-67.

217. Shustov A, Luzina I, Nguyen P, Papadimitriou JC, Handwerger B, Elkon $\mathrm{KB}$, et al. Role of perforin in controlling B-cell hyperactivity and humoral autoimmunity. J Clin Invest (2000) 106:R39-47. doi:10.1172/JCI8876

218. Perruche S, Marandin A, Kleinclauss F, Angonin R, Fresnay S, Baron MH, et al. Association of mixed hematopoietic chimerism with elevated circulating autoantibodies and chronic graft-versus-host disease occurrence. Transplantation (2006) 81:573-82. doi:10.1097/01.tp.0000183878. 53367.77

219. Patriarca F, Skert C, Bonifazi F, Sperotto A, Fili C, Stanzani M, et al. Effect on survival of the development of late-onset non-infectious pulmonary complications after stem cell transplantation. Haematologica (2006) 91:1268-72.

220. Sarantopoulos S, Stevenson KE, Kim HT, Bhuiya NS, Cutler CS, Soiffer RJ, et al. High levels of B-cell activating factor in patients with active chronic graftversus-host disease. Clin Cancer Res (2007) 13:6107-14. doi:10.1158/10780432.CCR-07-1290

221. Asavaroengchai W, Wang H, Wang S, Wang L, Bronson R, Sykes M, et al. An essential role for IFN-gamma in regulation of alloreactive CD8 T cells following allogeneic hematopoietic cell transplantation. Biol Blood Marrow Transplant (2007) 13:46-55. doi:10.1016/j.bbmt.2006.09.014

222. Sarantopoulos S, Stevenson KE, Kim HT, Cutler CS, Bhuiya NS, Schowalter M, et al. Altered B-cell homeostasis and excess BAFF in human chronic graft-versus-host disease. Blood (2009) 113:3865-74. doi:10.1182/ blood-2008-09-177840

223. Srinivasan M, Flynn R, Price A, Ranger A, Browning JL, Taylor PA, et al. Donor B-cell alloantibody deposition and germinal center formation are required for the development of murine chronic GVHD and bronchiolitis obliterans. Blood (2012) 119:1570-80. doi:10.1182/blood-2011-07-364414

224. Schultz KR, Paquet J, Bader S, HayGlass KT. Requirement for B cells in $\mathrm{T}$ cell priming to minor histocompatibility antigens and development of graft-versus-host disease. Bone Marrow Transplant (1995) 16:289-95.

225. Zorn E, Miklos DB, Floyd BH, Mattes-Ritz A, Guo L, Soiffer RJ, et al. Minor histocompatibility antigen DBY elicits a coordinated B and T cell response after allogeneic stem cell transplantation. J Exp Med (2004) 199:1133-42. doi:10.1084/jem.20031560

226. Young JS, Wu T, Chen Y, Zhao D, Liu H, Yi T, et al. Donor B cells in transplants augment clonal expansion and survival of pathogenic CD4+ T cells that mediate autoimmune-like chronic graft-versus-host disease. J Immunol (2012) 189:222-33. doi:10.4049/jimmunol.1200677

227. Via CS, Rus V, Gately MK, Finkelman FD. IL-12 stimulates the development of acute graft-versus-host disease in mice that normally would develop chronic, autoimmune graft-versus-host disease. J Immunol (1994) 153:4040-7.
228. Okubo T, Hagiwara E, Ohno S, Tsuji T, Ihata A, Ueda A, et al. Administration of an IL-12-encoding DNA plasmid prevents the development of chronic graft-versus-host disease (GVHD). J Immunol (1999) 162:4013-7.

229. De Wit D, Van Mechelen M, Zanin C, Doutrelepont JM, Velu T, Gérard C, et al. Preferential activation of Th2 cells in chronic graft-versus-host reaction. J Immunol (1993) 150:361-6.

230. Bogunia-Kubik K, Mlynarczewska A, Wysoczanska B, Lange A. Recipient interferon-gamma $3 / 3$ genotype contributes to the development of chronic graft-versus-host disease after allogeneic hematopoietic stem cell transplantation. Haematologica (2005) 90:425-6.

231. Watanabe Y, Kawakami H, Kawamoto H, Ikemoto Y, Masuda K, Takezaki E, et al. Effect of neonatal thymectomy on experimental autoimmune hepatitis in mice. Clin Exp Immunol (1987) 67:105-13.

232. Tung KS, Smith S, Matzner P, Kasai K, Oliver J, Feuchter F, et al. Murine autoimmune oophoritis, epididymoorchitis, and gastritis induced by day 3 thymectomy. Autoantibodies. Am J Pathol (1987) 126:303-14.

233. Sakoda Y, Hashimoto D, Asakura S, Takeuchi K, Harada M, Tanimoto M, et al. Donor-derived thymic-dependent T cells cause chronic graft-versushost disease. Blood (2007) 109:1756-64. doi:10.1182/blood-2006-08-042853

234. Zhang C, Todorov I, Zhang Z, Liu Y, Kandeel F, Forman S, et al. Donor CD4+ $\mathrm{T}$ and $\mathrm{B}$ cells in transplants induce chronic graft-versus-host disease with autoimmune manifestations. Blood (2006) 107:2993-3001. doi:10.1182/ blood-2005-09-3623

235. Anderson BE, McNiff JM, Jain D, Blazar BR, Shlomchik WD, Shlomchik MJ. Distinct roles for donor- and host-derived antigen-presenting cells and costimulatory molecules in murine chronic graft-versus-host disease: requirements depend on target organ. Blood (2005) 105:2227-34. doi:10.1182/blood-2004-08-3032

236. Na IK, Lu SX, Yim NL, Goldberg GL, Tsai J, Rao U, et al. The cytolytic molecules Fas ligand and TRAIL are required for murine thymic graft-versus-host disease. J Clin Invest (2010) 120:343-56. doi:10.1172/JCI39395

237. McCormick LL, Zhang Y, Tootell E, Gilliam AC. Anti-TGF-beta treatment prevents skin and lung fibrosis in murine sclerodermatous graft-versus-host disease: a model for human scleroderma. J Immunol (1999) 163:5693-9.

238. Olivieri A, Locatelli F, Zecca M, Sanna A, Cimminiello M, Raimondi R, et al. Imatinib for refractory chronic graft-versus-host disease with fibrotic features. Blood (2009) 114:709-18. doi:10.1182/blood-2009-02-204156

239. Magro L, Mohty M, Catteau B, Coiteux V, Chevallier P, Terriou L, et al. Imatinib mesylate as salvage therapy for refractory sclerotic chronic graft-versus-host disease. Blood (2009) 114:719-22. doi:10.1182/blood-2009-02-204750

240. Zerr P, Distler A, Palumbo-Zerr K, Tomcik M, Vollath S, Dees C, et al. Combined inhibition of $\mathrm{c}-\mathrm{Abl}$ and PDGF receptors for prevention and treatment of murine sclerodermatous chronic graft-versus-host disease. Am J Pathol (2012) 181:1672-80. doi:10.1016/j.ajpath.2012.07.017

241. Cutler C, Miklos D, Kim HT, Treister N, Woo SB, Bienfang D, et al. Rituximab for steroid-refractory chronic graft-versus-host disease. Blood (2006) 108:756-62. doi:10.1182/blood-2006-01-0233

242. Ratanatharathorn V, Ayash L, Reynolds C, Silver S, Reddy P, Becker M, et al. Treatment of chronic graft-versus-host disease with anti-CD20 chimeric monoclonal antibody. Biol Blood Marrow Transplant (2003) 9:505-11. doi:10.1016/S1083-8791(03)00216-7

243. Okamoto M, Okano A, Akamatsu S, Ashihara E, Inaba T, Takenaka H, et al. Rituximab is effective for steroid-refractory sclerodermatous chronic graft-versus-host disease. Leukemia (2006) 20:172-3. doi:10.1038/sj.leu. 2403996

244. Gong Q, Ou Q, Ye S, Lee WP, Cornelius J, Diehl L, et al. Importance of cellular microenvironment and circulatory dynamics in B cell immunotherapy. J Immunol (2005) 174:817-26. doi:10.4049/jimmunol.174.2.817

245. Zorn E, Kim HT, Lee SJ, Floyd BH, Litsa D, Arumugarajah S, et al. Reduced frequency of FOXP3 + CD4+CD25+ regulatory T cells in patients with chronic graft-versus-host disease. Blood (2005) 106:2903-11. doi:10.1182/ blood-2005-03-1257

246. Rieger K, Loddenkemper C, Maul J, Fietz T, Wolff D, Terpe H, et al. Mucosal FOXP3+ regulatory $\mathrm{T}$ cells are numerically deficient in acute and chronic GvHD. Blood (2006) 107:1717-23. doi:10.1182/blood-200506-2529

247. Taylor PA, Lees CJ, Blazar BR. The infusion of ex vivo activated and expanded $\mathrm{CD} 4(+) \mathrm{CD} 25(+)$ immune regulatory cells inhibits graft-versus-host disease lethality. Blood (2002) 99:3493-9. doi:10.1182/blood.V99.10.3493 
248. Koreth J, Matsuoka K, Kim HT, McDonough SM, Bindra B, Alyea EP III, et al. Interleukin-2 and regulatory T cells in graft-versus-host disease. $N$ Engl J Med (2011) 365:2055-66. doi:10.1056/NEJMoa1108188

249. Hakim F, Fowler DH, Shearer GM, Gress RE. Animal models of acute and chronic graft-versus-host disease. Curr Protoc Immunol (2001) Chapter 4:Unit4.3. doi:10.1002/0471142735.im0403s27

250. Storb R, Epstein RB, Ragde H, Bryant J, Thomas ED. Marrow engraftment by allogeneic leukocytes in lethally irradiated dogs. Blood (1967) 30:805-11.

251. Rosinski SL, Stone B, Graves SS, Fuller DH, De Rosa SC, Spies GA, et al. Development of a minor histocompatibility antigen vaccine regimen in the canine model of hematopoietic cell transplantation. Transplantation (2015) 99:2083-94. doi:10.1097/TP.0000000000000744

252. Ferrara JL, Reddy P. Pathophysiology of graft-versus-host disease. Semin Hematol (2006) 43:3-10. doi:10.1053/j.seminhematol.2005.09.001

253. Hulsdunker J, Zeiser R. Insights into the pathogenesis of GvHD: what mice can teach us about man. Tissue Antigens (2015) 85:2-9. doi:10.1111/tan.12497

254. Reddy P, Negrin R, Hill GR. Mouse models of bone marrow transplantation. Biol Blood Marrow Transplant (2008) 14:129-35. doi:10.1016/j. bbmt.2007.10.021

255. Yap KK. Modelling human development and disease: the role of animals, stem cells, and future perspectives. Aust Med Stud J (2012) 3:8-10.

256. Kihara T, Morita H, Kitano Y. Studies on transient graft-versus-host disease in $\mathrm{BALB} / \mathrm{c}$ nude mice injected with allogeneic C57BL/6 splenocytes. J Dermatol Sci (1996) 11:76-83. doi:10.1016/0923-1811(95)00423-8

257. Sprent J, Schaefer M, Korngold R. Role of T cell subsets in lethal graft-versushost disease (GVHD) directed to class I versus class II H-2 differences. II. Protective effects of L3T4+ cells in anti-class II GVHD. J Immunol (1990) 144:2946-54.

258. Ali N, Flutter B, Sanchez Rodriguez R, Sharif-Paghaleh E, Barber LD, Lombardi G, et al. Xenogeneic graft-versus-host-disease in NOD-scid IL-2Rgammanull mice display a T-effector memory phenotype. PLoS One (2012) 7:e44219. doi:10.1371/journal.pone.0044219

259. Becker C, Taube C, Bopp T, Becker C, Michel K, Kubach J, et al. Protection from graft-versus-host disease by HIV-1 envelope protein gp120-mediated activation of human CD4+CD25+ regulatory T cells. Blood (2009) 114:1263-9. doi:10.1182/blood-2009-02-206730

260. Bohana-Kashtan O, Morisot S, Hildreth R, Brayton C, Levitsky HI, Civin CI. Selective reduction of graft-versus-host disease-mediating human $\mathrm{T}$ cells by ex vivo treatment with soluble Fas ligand. J Immunol (2009) 183:696-705. doi:10.4049/jimmunol.0800561

261. King MA, Covassin L, Brehm MA, Racki W, Pearson T, Leif J, et al. Human peripheral blood leucocyte non-obese diabetic-severe combined immunodeficiency interleukin-2 receptor gamma chain gene mouse model of xenogeneic graft-versus-host-like disease and the role of host major histocompatibility complex. Clin Exp Immunol (2009) 157:104-18. doi:10.1111/j.1365-2249.2009.03933.x

262. Brehm MA, Shultz LD, Luban J, Greiner DL. Overcoming current limitations in humanized mouse research. J Infect Dis (2013) 208(Suppl 2):S125-30. doi:10.1093/infdis/jit319

263. Zinöcker S, Dressel R, Wang XN, Dickinson AM, Rolstad B. Immune reconstitution and graft-versus-host reactions in rat models of allogeneic hematopoietic cell transplantation. Front Immunol (2012) 3:355. doi:10.3389/ fimmu.2012.00355

264. Konstandin MH, Wabnitz GH, Aksoy H, Kirchgessner H, Dengler TJ, Samstag Y. A sensitive assay for the quantification of integrin-mediated adhesiveness of human stem cells and leukocyte subpopulations in whole blood. J Immunol Methods (2007) 327:30-9. doi:10.1016/j.jim.2007.07.005

265. Lin JY, Tsai FC, Wallace CG, Huang WC, Wei FC, Liao SK. Optimizing chimerism level through bone marrow transplantation and irradiation to induce long-term tolerance to composite tissue allotransplantation. J Surg Res (2012) 178:487-93. doi:10.1016/j.jss.2012.02.064

266. Vogelsang GB, Santos GW, Colvin OM, Chen T. Thalidomide for graftversus-host disease. Lancet (1988) 1:827. doi:10.1016/S0140-6736(88) 91690-X

267. Pakkala I, Taskinen E, Pakkala S, Raisanen-Sokolowski A. MC1288, a vitamin D analog, prevents acute graft-versus-host disease in rat bone marrow transplantation. Bone Marrow Transplant (2001) 27:863-7. doi:10.1038/ sj.bmt. 1702873
268. Gendelman M, Hecht T, Logan B, Vodanovic-Jankovic S, Komorowski R, Drobyski WR. Host conditioning is a primary determinant in modulating the effect of IL-7 on murine graft-versus-host disease. J Immunol (2004) 172:3328-36. doi:10.4049/jimmunol.172.5.3328

269. Mabed M, Maroof S, Zalta K, El-Awadee M. Delayed or delayed sequential bone marrow transplantation: relevance for acute graft-versus-host disease prevention after major $\mathrm{H} 2$ incompatible transplantation. Bone Marrow Transplant (2005) 35:803-6. doi:10.1038/sj.bmt.1704877

270. Schwarte S, Hoffmann MW. Influence of radiation protocols on graft-vshost disease incidence after bone-marrow transplantation in experimental models. Methods Mol Med (2005) 109:445-58.

271. Zeiser R, Nguyen VH, Hou JZ, Beilhack A, Zambricki E, Buess M, et al. Early CD30 signaling is critical for adoptively transferred CD4+CD25+ regulatory $\mathrm{T}$ cells in prevention of acute graft-versus-host disease. Blood (2007) 109:2225-33. doi:10.1182/blood-2006-07-038455

272. Sadeghi B, Aghdami N, Hassan Z, Forouzanfar M, Rozell B, Abedi-Valugerdi $\mathrm{M}$, et al. GVHD after chemotherapy conditioning in allogeneic transplanted mice. Bone Marrow Transplant (2008) 42:807-18. doi:10.1038/bmt. 2008.261

273. Riesner K, Kalupa M, Shi Y, Elezkurtaj S, Penack O. A preclinical acute GVHD mouse model based on chemotherapy conditioning and MHC-matched transplantation. Bone Marrow Transplant (2015) 51:410-7. doi:10.1038/ bmt.2015.279

274. Seok J, Warren HS, Cuenca AG, Mindrinos MN, Baker HV, Xu W, et al. Genomic responses in mouse models poorly mimic human inflammatory diseases. Proc Natl Acad Sci U S A (2013) 110:3507-12. doi:10.1073/ pnas. 1222878110

275. Teshima T, Hill GR, Pan L, Brinson YS, van den Brink MR, Cooke KR, et al. IL-11 separates graft-versus-leukemia effects from graft-versus-host disease after bone marrow transplantation. J Clin Invest (1999) 104:317-25. doi:10.1172/JCI7111

276. Antin JH, Lee SJ, Neuberg D, Alyea E, Soiffer RJ, Sonis S, et al. A phase I/ II double-blind, placebo-controlled study of recombinant human interleukin-11 for mucositis and acute GVHD prevention in allogeneic stem cell transplantation. Bone Marrow Transplant (2002) 29:373-7. doi:10.1038/ sj.bmt. 1703394

277. Ferrara JL, Cooke KR, Pan L, Krenger W. The immunopathophysiology of acute graft-versus-host-disease. Stem Cells (1996) 14:473-89. doi:10.1002/ stem. 140473

278. Anasetti C, Martin PJ, Hansen JA, Appelbaum FR, Beatty PG, Doney K, et al. A phase I-II study evaluating the murine anti-IL-2 receptor antibody 2A3 for treatment of acute graft-versus-host disease. Transplantation (1990) 50:49-54. doi:10.1097/00007890-199007000-00010

279. Belanger C. Use of an anti-interleukine 2 receptor monoclonal antibody for GvHD prophylaxis in unrelated bone marrow transplantation. GEGMO Group. Bone Marrow Transplant (1993) 11(Suppl 1):112-3.

280. Stevens JC, Banks GT, Festing MF, Fisher EM. Quiet mutations in inbred strains of mice. Trends Mol Med (2007) 13:512-9. doi:10.1016/j. molmed.2007.10.001

281. Storb R, Deeg HJ, Whitehead J, Appelbaum F, Beatty P, Bensinger W, et al. Methotrexate and cyclosporine compared with cyclosporine alone for prophylaxis of acute graft versus host disease after marrow transplantation for leukemia. N Engl J Med (1986) 314:729-35. doi:10.1056/ NEJM198603203141201

282. Mestas J, Hughes CC. Of mice and not men: differences between mouse and human immunology. J Immunol (2004) 172:2731-8. doi:10.4049/ jimmunol.172.5.2731

283. Ordemann R, Hutchinson R, Friedman J, Burakoff SJ, Reddy P, Duffner U, et al. Enhanced allostimulatory activity of host antigen-presenting cells in old mice intensifies acute graft-versus-host disease. J Clin Invest (2002) 109:1249-56. doi:10.1172/JCI0214793

284. Wang XN, Collin M, Sviland L, Marshall S, Jackson G, Schulz U, et al. Skin explant model of human graft-versus-host disease: prediction of clinical outcome and correlation with biological risk factors. Biol Blood Marrow Transplant (2006) 12:152-9. doi:10.1016/j.bbmt.2005.11.188

285. Sviland L, Dickinson AM. A human skin explant model for predicting graftversus-host disease following bone marrow transplantation. JClin Pathol (1999) 52:910-3. doi:10.1136/jcp.52.12.910 
286. Vogelsang GB, Hess AD, Berkman AW, Tutschka PJ, Farmer ER, Converse PJ, et al. An in vitro predictive test for graft versus host disease in patients with genotypic HLA-identical bone marrow transplants. N Engl J Med (1985) 313:645-50. doi:10.1056/NEJM198509123131101

287. Novota P, Zinöcker S, Norden J, Wang XN, Sviland L, Opitz L, et al. Expression profiling of major histocompatibility and natural killer complex genes reveals candidates for controlling risk of graft versus host disease. PLoS One (2011) 6:e16582. doi:10.1371/journal.pone.0016582

288. Jucker M. The benefits and limitations of animal models for translational research in neurodegenerative diseases. Nat Med (2010) 16:1210-4. doi:10.1038/nm.2224

289. Chu YW, Gress RE. Murine models of chronic graft-versus-host disease: insights and unresolved issues. Biol Blood Marrow Transplant (2008) 14:365-78. doi:10.1016/j.bbmt.2007.12.002

290. Socie G, Blazar BR. Acute graft-versus-host disease: from the bench to the bedside. Blood (2009) 114:4327-36. doi:10.1182/blood-2009-06-204669
291. Kilkenny C, Parsons N, Kadyszewski E, Festing MF, Cuthill IC, Fry D, et al. Survey of the quality of experimental design, statistical analysis and reporting of research using animals. PLoS One (2009) 4:e7824. doi:10.1371/journal. pone. 0007824

Conflict of Interest Statement: The authors declare that the research was conducted in the absence of any commercial or financial relationships that could be construed as a potential conflict of interest.

Copyright (c) 2016 Boieri, Shah, Dressel and Inngjerdingen. This is an open-access article distributed under the terms of the Creative Commons Attribution License (CC BY). The use, distribution or reproduction in other forums is permitted, provided the original author(s) or licensor are credited and that the original publication in this journal is cited, in accordance with accepted academic practice. No use, distribution or reproduction is permitted which does not comply with these terms. 